\title{
Charakterystyka lessów lubelskich jako podłoża budowlanego
}

\author{
Krzysztof Nepelski ${ }^{1}$
}

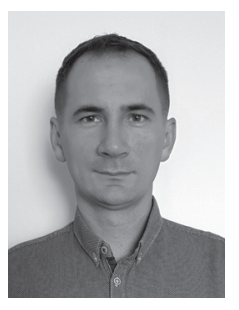

Characteristics of the Lublin loess as a building subsoil. Prz. Geol., 69: 835-849; doi: 10.7306/2021.45

A b s tra ct. The loess subsoil constitutes over 50\% of the Lublin area and determines the geotechnical conditions of the western side of the River Bystrzyca. The paper discusses the geological structure of this part of Lublin and presents an analysis of the results of field research carried out by the author. The research methodology and the method of deriving parameters for the loess subsoil are also proposed. The Lublin loesses were divided into three main facies groups: aeolian (typical loess), aeolian-diluvial and aeolian-alluvial. The basis for the division and parametric characteristics of individual facies were mainly in-situ tests: CPT/CPTU static soundings, DMT/SDMT flat dilatometer tests and PMT Menard pressuremeter tests. The collected data allowed characterizing each of the facies groups and developing a synthetic geological cross-section representing the geological structure of the western part of Lublin. The number of analysed tests allowed stating that the data from CPT/CPTU static soundings are representative for Lublin. Data from DMT/SDMT tests can be considered representative, but further research is needed to refine them and, for example, to separate them by facies. Data from pressuremeter tests should be treated as preliminary. The analyses show that the most common facies in Lublin is silty aeolian one called typical loess, which, according to the author, constitutes approximately $75-80 \%$, and their parameters are of key importance for the design of buildings. The remaining facies groups are about 8-15\% for aeolian-diluvial loess and 8-10\% for aeolian alluvial loess. Typical loesses are macroscopically homogeneous, but their varying stiffness is reflected in in-situ tests. The basic research method for loess subsoil should be CPT/CPTU static soundings, while the most representative parameter for geotechnical layers is the cone resistance qc. Details of the geological structure and parameters should be performed with DMT, SDMT and PMT tests, as well as laboratory tests, the necessary scope of which can be determined after the development of the subsoil model from the results of CPT tests.

Keywords: pressuremeter tests, CPTU, DMT, loess facies types, loess

Lublin jest położony na terenie Płaskowyżu Nałęczowskiego, którego zachodnią granicę wyznacza rzeka Wisła w rejonie Kazimierza Dolnego, natomiast wschodnią - Bystrzyca przepływającą przez Lublin. Płaskowyż Nałęczowski charakteryzuje się występowaniem pokrywy lessowej o przeciętnej miąższości kilkunastu metrów, a lokalnie dochodzącej nawet do $30 \mathrm{~m}$. Pod względem litologicznym lessy lubelskie to głównie pyły oraz w mniejszym stopniu gliny pylaste i piaski pylaste.

W artykule omówiono budowę geologiczną lessowej części Lublina, przedstawiono zbiorczą analizę wyników badań terenowych wykonanych przez autora $\mathrm{z}$ odniesieniem do rezultatów innych badaczy, a także podano propozycje metodyki badawczej i wyprowadzania parametrów dla podłoża lessowego.

\section{PODLOŻE LESSOWE W REJONIE LUBLINA}

Podłoże lessowe stanowi przeszło 50\% powierzchni Lublina i determinuje warunki geotechniczne lewobrzeżnej zlewni Bystrzycy. Lessy w rejonie Lublina współtworzą podłoże zwykle o korzystnych właściwościach do posadowienia obiektów budowlanych.

Utwory lessowe oraz lessopodobne to grunty, które co do zasady powstały przy współudziale wiatru. Jednak nie tylko procesy eoliczne miały wpływ na ostateczne właściwości takiego podłoża. Równolegle lub w późniejszym stadium zachodziły także inne zjawiska (np. spływanie, spełzanie, zsuwanie, akumulacja wodna), które wykreowały dzisiejszą formę gruntu oraz jego cechy.
Biorąc pod uwagę wszystkie procesy protogenetyczne, syngenetyczne oraz epigenetyczne, w zakresie lessów wydziela się facje, które charakteryzują się zróżnicowanymi cechami. Różnorodność lessów klarownie przedstawiają klasyfikacje Maruszczaka (2000), który podzielił je w zależności od składu granulometrycznego, genezy oraz ukształtowania terenu (tab. 1).

Inny badacz lessów, Malinowski (1971), dzielił je na eoliczne (subarealne), dolinne (aluwialne) i soliflukcyjne oraz wyodrębnił pięć poziomów stratygraficznych, z czego cztery są związane z glacjalnymi cyklami sedymentacyjnymi, a piąty (najmłodszy) jest postglacjalny. Poszczególne poziomy lessowe są rozdzielane lessami gliniastymi, często z warstwą humusową, ułatwiającą identyfikację genetyczną, gdyż jest ona wynikiem wietrzeń z okresów interglacjalnych.

Według autora, w badaniach podłoża na cele budowlane, a więc w opracowaniach geotechnicznych i geologiczno-inżynierskich, na obszarze Lublina należy wyodrębniać trzy główne grupy facjalne: eoliczną (lessy typowe), eoliczno-deluwialną oraz eoliczno-aluwialną. Określenie grupa facjalna (a nie facja) jest tu celowe, ponieważ w obrębie wydzielonej grupy mogą znajdować się także lessy innych facji, lecz o znacznie mniejszym zasięgu. Zaproponowany podział jest nieco uproszczony w stosunku do klasyfikacji Maruszczaka (2000), lecz obejmuje najważniejsze procesy genetyczne, najczęściej identyfikowane na obszarze Lublina. Zaproponowanych wydzieleń nie należy jednak ściśle łączyć w ujęciu genetycznym z nazwą grupy. Nazwy poszczególnych grup stanowią raczej umowny tytuł podkreślający protogenetyczny wpływ procesów eolicznych, które $\mathrm{w}$ połączeniu z syngenetycznymi i postgenetycznymi

${ }^{1}$ Politechnika Lubelska, Wydział Budownictwa i Architektury, ul. Nadbystrzycka 40, 20-618 Lublin; k.nepelski@pollub.pl. 
Tab. 1. Podział lessów wg Maruszczaka (2000)

Table 1. Division of loess acc. to Maruszczak (2000)

\begin{tabular}{|c|c|c|}
\hline $\begin{array}{l}\text { Odmiany granulometryczne } \\
\text { Granular type of the loess }\end{array}$ & $\begin{array}{c}\text { Odmiany genetyczno-facjalne } \\
\text { Facies type of the loess }\end{array}$ & $\begin{array}{c}\text { Klasyfikacja wg uksztaltowania terenu } \\
\text { Landform type of the loess }\end{array}$ \\
\hline $\begin{array}{l}\text { lessy gliniaste } \\
\text { clayey loess } \\
\text { lessy (pylaste) } \\
\text { silty loess } \\
\text { lessy piaszczyste } \\
\text { sandy loess }\end{array}$ & $\begin{array}{l}\text { eoliczna } \\
\text { aeolian } \\
\text { eoliczno-deluwialna } \\
\text { aeolian-diluvial } \\
\text { eoliczno-soliflukcyjna } \\
\text { aeolian-solifluction } \\
\text { eoliczno-koluwialna } \\
\text { aeolian-colluvial } \\
\text { eoliczno-limniczna } \\
\text { aeolian-limnic } \\
\text { eoliczno-aluwialna } \\
\text { aeolian-alluvial }\end{array}$ & $\begin{array}{l}\text { lessy wierzchowinowe } \\
\text { interfluve loess } \\
\text { lessy stokowe } \\
\text { slope loess } \\
\text { lessy dolinne } \\
\text { valley loess }\end{array}$ \\
\hline
\end{tabular}

procesami deluwialnymi i aluwialnymi wykształciły właściwości danej grupy. Dlatego do poszczególnych grup facjalnych są zaliczane również utwory będące wynikiem procesów pokrewnych (np. koluwialnych, soliflukcyjnych i limnicznych), występujących jednak w dużo mniejszym zakresie.

W Lublinie najbardziej jest rozpowszechniona facja eoliczna, tzw. lessy typowe, których miąższość osiąga kilkanaście metrów. W ujęciu granulometrycznym są to osady pylaste, makroskopowo jednorodne, sporadycznie z cienkimi przewarstwieniami piaszczystymi. Zazwyczaj barwy jasnobeżowej lub żółtej, o niskiej wilgotności i konsystencji zwartej lub twardoplastycznej wg normy PN-EN ISO 14688-1. Uplastycznienia w obrębie lessów eolicznych młodszych, czyli poziomu IV i V, występują jedynie w stropie lub spągu tej warstwy. W niektórych częściach Lublina w głębszych partiach podłoża można wydzielić także lessy eoliczne starsze, poziomu III wg Malinowskiego (1971). W lessach eolicznych starszych często występuje zwiększona zawartość frakcji piaszczystej, przez co część z nich klasyfikowana jest jako pył piaszczysty, a także zwiększona wilgotność, powodująca zaliczenie ich do konsystencji twardoplastycznej.

Grupa facjalna eoliczno-deluwialna to głównie lessy młodsze występujące przypowierzchniowo, lecz także częściowo lessy starsze, tworzące warstwę rozdzielającą (gliniastą) typowe utwory eoliczne akumulowane w różnych okresach. Większa ich miąższość występuje u podnóża zboczy, a także w obniżeniach terenu na wierzchowinach. Utwory te charakteryzują się zwiększoną zawartością cząstek ilastych, przez co zazwyczaj są klasyfikowane jako gliny i gliny pylaste oraz wyższą wilgotnością i konsystencją twardoplastyczną bądź plastyczną. Najczęściej są ciemnobrązowe lub ciemnobeżowe. Zauważalne są także liczne smugowania oraz naprzemienne występujące cienkie warstewki mniej lub bardziej gliniaste.

Grupa facjalna eoliczno-aluwialna to lessy poziomu I i II wg Malinowskiego (1971), które występują w głębszych partiach podłoża, poniżej lessów typowych. Utwory te są ułożone bezpośrednio na podłożu zwietrzelinowo-skalistym lub wodnolodowcowych piaskach. W porównaniu do lessów typowych, facja ta jest dużo bardziej niejednorodna, co uwidacznia się zarówno w ocenie makroskopowej, jak i parametrach sondowań. Litologicznie grunty te są klasyfikowane jako gliny lub gliny pylaste, niejednokrotnie $\mathrm{z}$ przewarstwieniami piasków i piasków pylastych. W obrębie facji występują liczne smugowania i warstwowania, a grunt jest ciemniejszej barwy, zwykle ciemnobeżowy, szary, szarobeżowy lub brązowy.

Poglądowo widok poszczególnych typów lessów w wykopach budowlanych przedstawiono na rycinie 1.

W dalszej części artykułu przedstawiono wyniki badań terenowych prowadzonych przez autora w Lublinie i okolicach na obszarze zalegania pokrywy lessowej. Na mapie (ryc. 2) przedstawiono lokalizację poletek badawczych. Podstawową metodą badań były sondowania statyczne CPT/CPTU (częściowo wykonano testy CPTM ze stożkiem mechanicznym) oraz odwierty badawcze. Dodatkowo w wybranych lokalizacjach przeprowadzano testy dylatometrem płaskim (DMT) częściowo z pomiarem sejsmicznym (SDMT), a także badania presjometrem Menarda (PMT).

Po analizie lokalnej budowy geologicznej wybranych rejonów Lublina, opracowano także reprezentatywny przekrój (ryc. 3), który ideowo odzwierciedla budowę geologiczną zachodniej, czyli lessowej, części Lublina.

\section{SZTYWNOŚĆ PODLOŻA GRUNTOWEGO}

Badania podłoża gruntowego mają na celu wyznaczenie parametrów służących do opisu jego zachowania. W ujęciu inżynierskim największe znaczenie mają parametry odkształceniowe i wytrzymałościowe. Podłoże gruntowe to ośrodek o silnie nieliniowym zachowaniu. Sztywność gruntu jest zmienna i zależy m.in. od zakresu odkształceń i naprężeń jakie są rozpatrywane. Zmianę sztywności podłoża gruntowego wraz z typowymi metodami badawczymi przedstawia wykres Atkinsona (Atkinson, Sallfors, 1991) (ryc. 4).

W dalszej części pracy przedstawiono parametry odkształceniowe lessów uzyskiwane różnymi metodami badawczymi (DMT, SDMT, CPTU, PMT, badania laboratoryjne). Wartości otrzymane z różnych badań różnią się od siebie, ponieważ są wykonywane przy odmiennych warunkach brzegowych i odzwierciedlają pracę podłoża w różnym zakresie odkształceń. Edometryczne moduły ściśliwości lessów lubelskich wg różnych badaczy wahają się w zakresie 4-20 MPa, jednak rzeczywiste osiadania budynków są znacznie mniejsze niż szacowane $z$ wykorzystaniem tych parametrów. Przyczyn uzyskania niskich wartości modułów w edometrach jest wiele. Wiłun (2013) podawał, że wyniki z badań edometrycznych są obarczone błędami m.in. ze względu na naruszenie struktury podczas pobierania próbek w otworze wiertniczym oraz przy przemieszczaniu do pierścienia edometru, znacznie większe spadki 

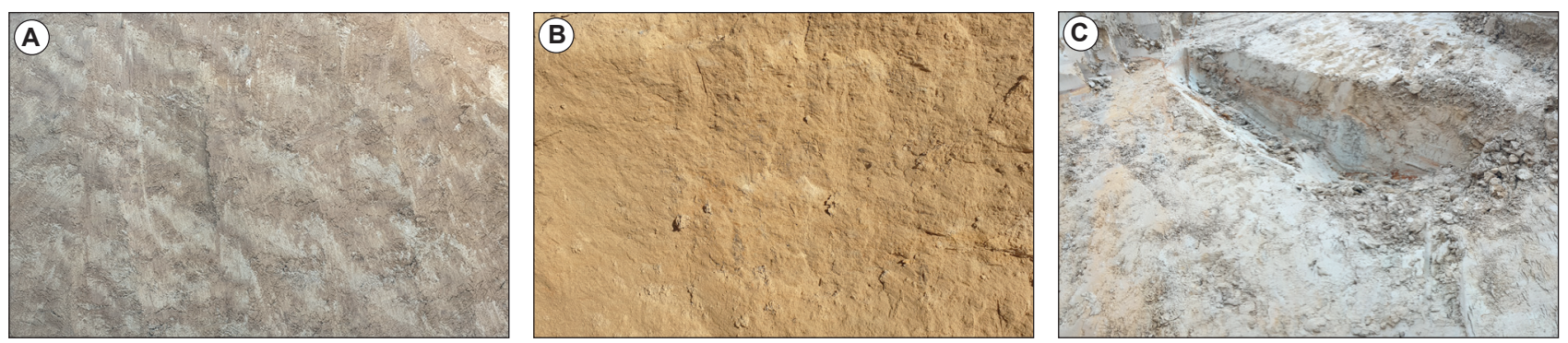

Ryc. 1. Lessy w wykopach budowlanych na terenie Lublina: A - deluwialne, B - eoliczne, $\mathbf{C}$ - aluwialne

Fig. 1. Loess in construction excavations in the Lublin area: $\mathbf{A}$ - diluvial, $\mathbf{B}$ - aeolian, $\mathbf{C}-$ alluvial

hydrauliczne podczas badania w stosunku do panujących w naturze, niedokładność przylegania gruntu do pierścienia edometru i filtrów oraz odkształcenia własne edometru. Problematyka jakości pobieranych próbek jest podnoszona i analizowana przez badaczy z wielu instytutów na całym świecie. Lunne i in. (2006) przeanalizowali na gruntach norweskich wpływ jakości pobieranych próbek m.in. na wyniki badań edometrycznych. W badaniach wykazali, że wartości modułów edometrycznych mogą być nawet 40-50\% niższe przy próbkach o nieodpowiedniej jakości. Jednak nawet eliminując lub minimalizując powyższe czynniki, uzyskane moduły edometryczne w dalszym ciągu odpowiadają zakresowi dużych odkształceń. Pod typowymi fundamentami zakres odkształceń jest zazwyczaj mniejszy, a na większych głębokościach dużo mniejszy. W przy- padku lessów moduły ściśliwości wyznaczone w edometrach nie powinny być stosowane bezpośrednio do szacowania osiadania, gdyż wartości te są zawyżone. Znacznie lepiej rzeczywiste osiadanie odzwierciedlają parametry wyznaczone z badań DMT lub wyprowadzone z testów CPT z wykorzystaniem odpowiednio skalibrowanych formuł (Nepelski, 2020).

\section{SONDOWANIA STATYCZNE CPT/CPTU}

Jednym z najpopularniejszych badań polowych są sondowania statyczne CPT, które dostarczają quasi-ciągłych danych na głębokości. Testy umożliwiają zbadanie profilu podłoża do znacznych głębokości, w stosunkowo szybkim czasie i przy niewielkim nakładzie finansowym. Zebrane

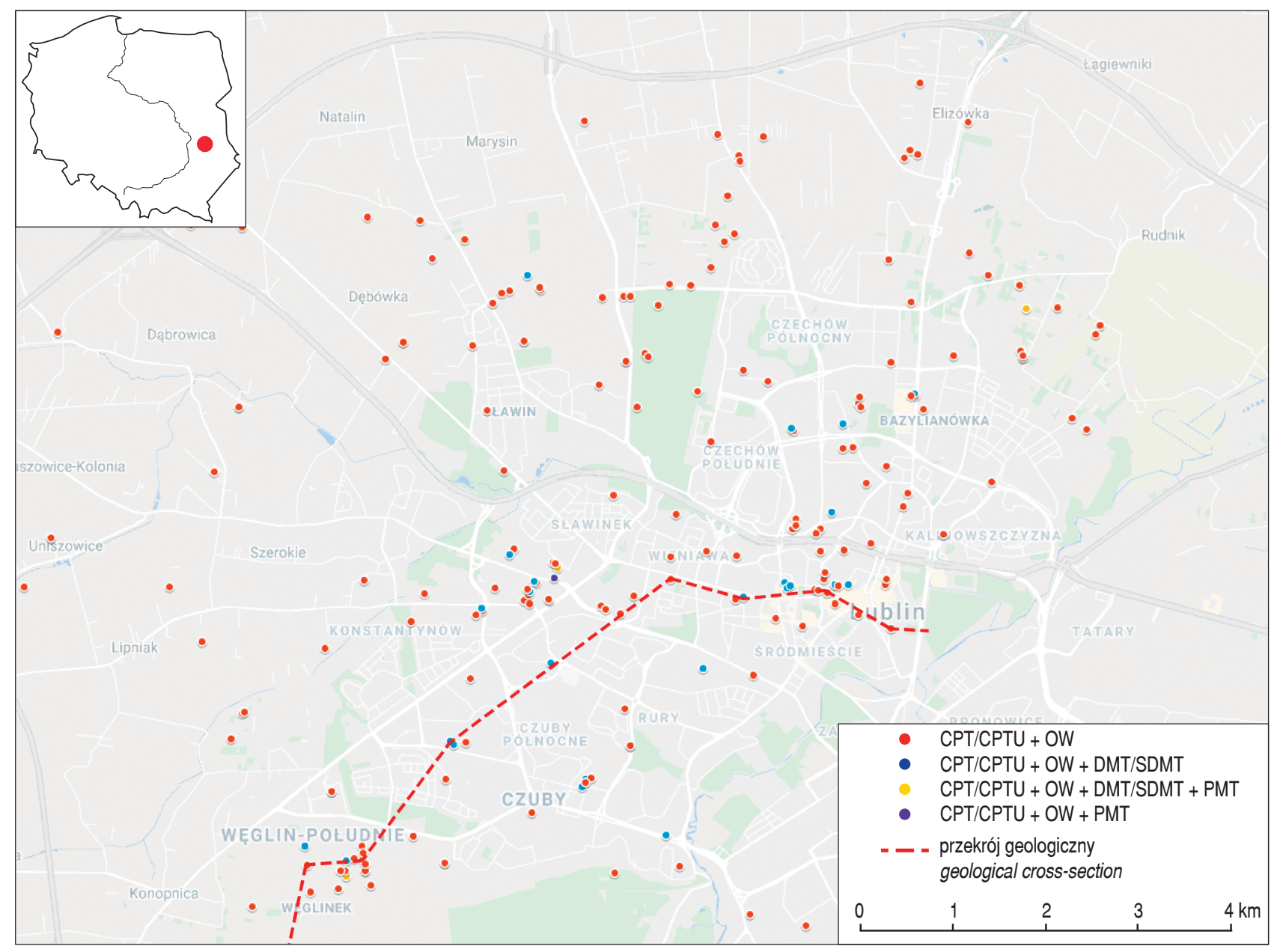

Ryc. 2. Mapa Lublina z lokalizacją poletek badawczych (opracowano na podkładzie mapy z https://www.google.pl/maps)

Fig. 2. Map of Lublin with the location of the research plots (based on the background map from https://www.google.pl/maps) 


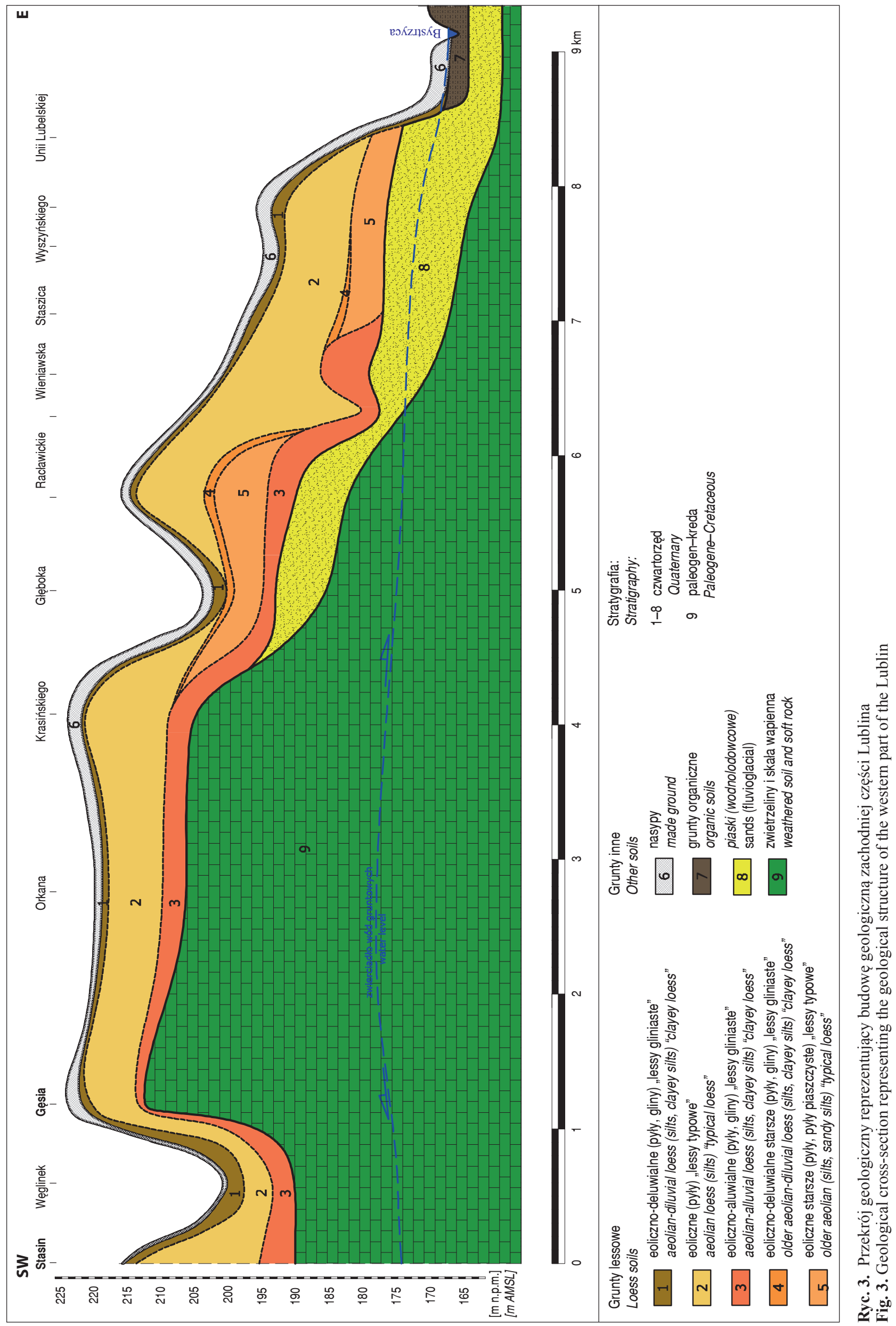




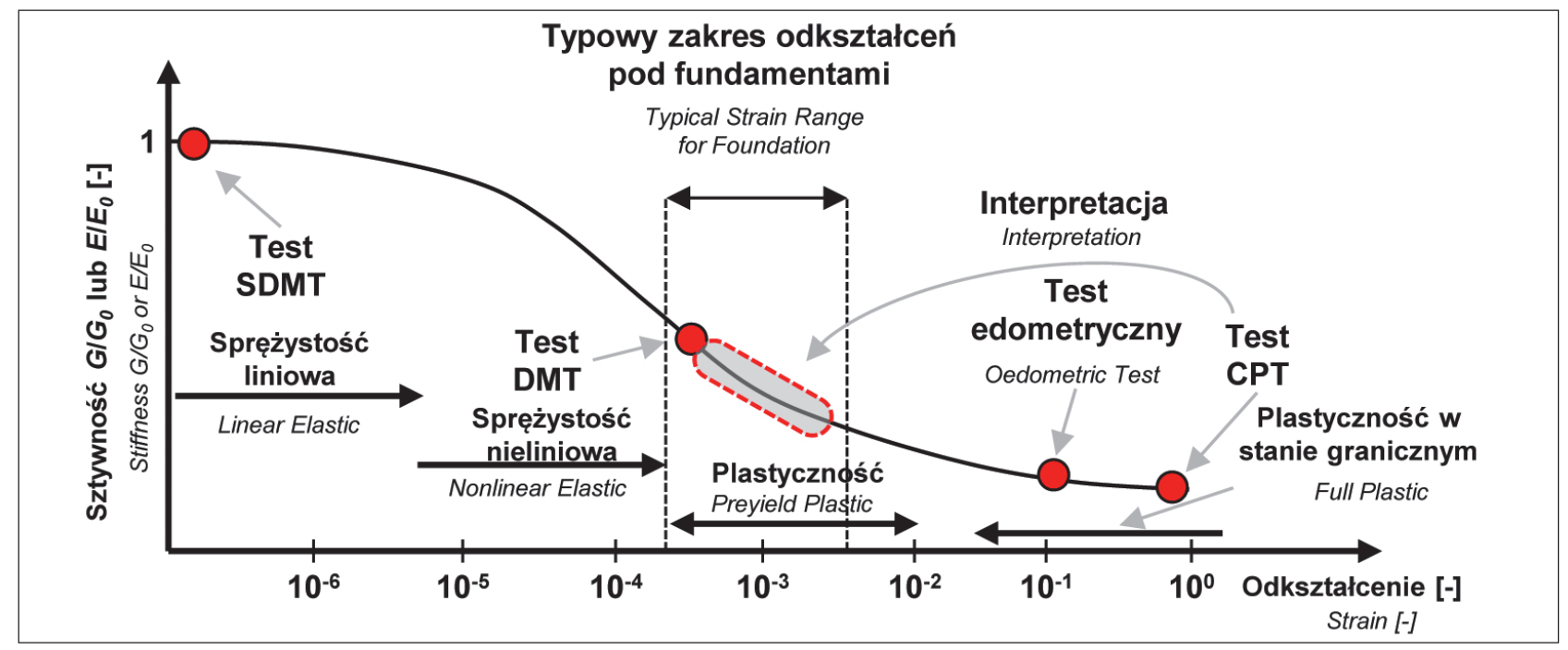

Ryc. 4. Krzywa degradacji sztywności podłoża gruntowego (na podstawie Atkinsona [Atkinson, Sallfors, 1991])

Fig. 4. The soil stiffness degradation curve (after Atkinson [Atkinson, Sallfors, 1991])

podczas badania dane pozwalają następnie $\mathrm{z}$ zastosowaniem formuł interpretacyjnych na wyprowadzenie licznych parametrów geotechnicznych (Kulhawy, Mayne, 1990; Mayne, 2020). Sondowanie CPT jest obecnie najbardziej uniwersalnym testem gruntu, a liczne korelacje służą zarówno do wyprowadzania parametrów gruntu, jak i rozpoznawania jego rodzaju (Fellenius, Eslami, 2000; Powell, Lunne, 2005; Robertson, 2009b; Godlewski, 2013; Nepelski, Rudko, 2018; Rabarijoely, 2019; Mayne, 2020). W Polsce do interpretacji rodzaju gruntu szeroko stosowany jest nomogram SBT (Soil Bahaviour Type) Robertsona i in. (1986), który został zmodyfikowany i dostosowany do polskich warunków przez Młynarka i in. (1997). Według autora analiza wartości oraz zmienności parametrów sondowania jest przydatna również do identyfikacji genezy gruntu i zaliczenia go do grupy facjalnej.

Na rycinie 5 przedstawiono wykresy dla reprezentatywnego sondowania CPTU w lessach lubelskich. Na wykresie dokonano podziału facjalnego, który umożliwia scharakteryzowanie poszczególnych stref. Strefa przypowierzchniowa, eoliczno-deluwialna $(0,0-1,0 \mathrm{~m}$ p.p.t), charakteryzuje się obniżonymi oporami stożka $q_{\mathrm{c}}$ oraz wartościami $u_{2}$ bliskim zeru, ponadto zwykle zwiększonym wskaźnikiem $R_{\mathrm{f}}$, co jednak w przypadku sondowania przedstawionego na rycinie 5 nie miało miejsca. Strefa lessów typowych - eolicznych $(1,0-6,0$ m p.p.t), to wyższe wartości $q$ oraz brak zarejestrowanego ciśnienia wody w porach $u_{2}$. Wskaźnik $R_{\mathrm{f}}$ przyjmuje wartość ok. $2 \%$ i ma ,stabilny” przebieg. W lessach eoliczno-deluwialnych starszych $(6,0-8,0 \mathrm{~m}$ p.p.t) następuje spadek $q_{\mathrm{c}}$ oraz znaczny wzrost $R_{\mathrm{f}} \mathrm{i} u_{2}$. Do facji tej umownie włączono również występującą w zakresie 6,07,0 $\mathrm{m}$ przejściową warstwę lessów typowych, częściowo uplastycznionych, akumulowanych w początkowym stadium na deluwiach starszych. Występujące w zakresie głębokości 8,0-9,0 m niewielkie przewarstwienie lessów eolicznych starszych charakteryzuje się wzrostem $q_{\mathrm{c}}(\mathrm{dla}$

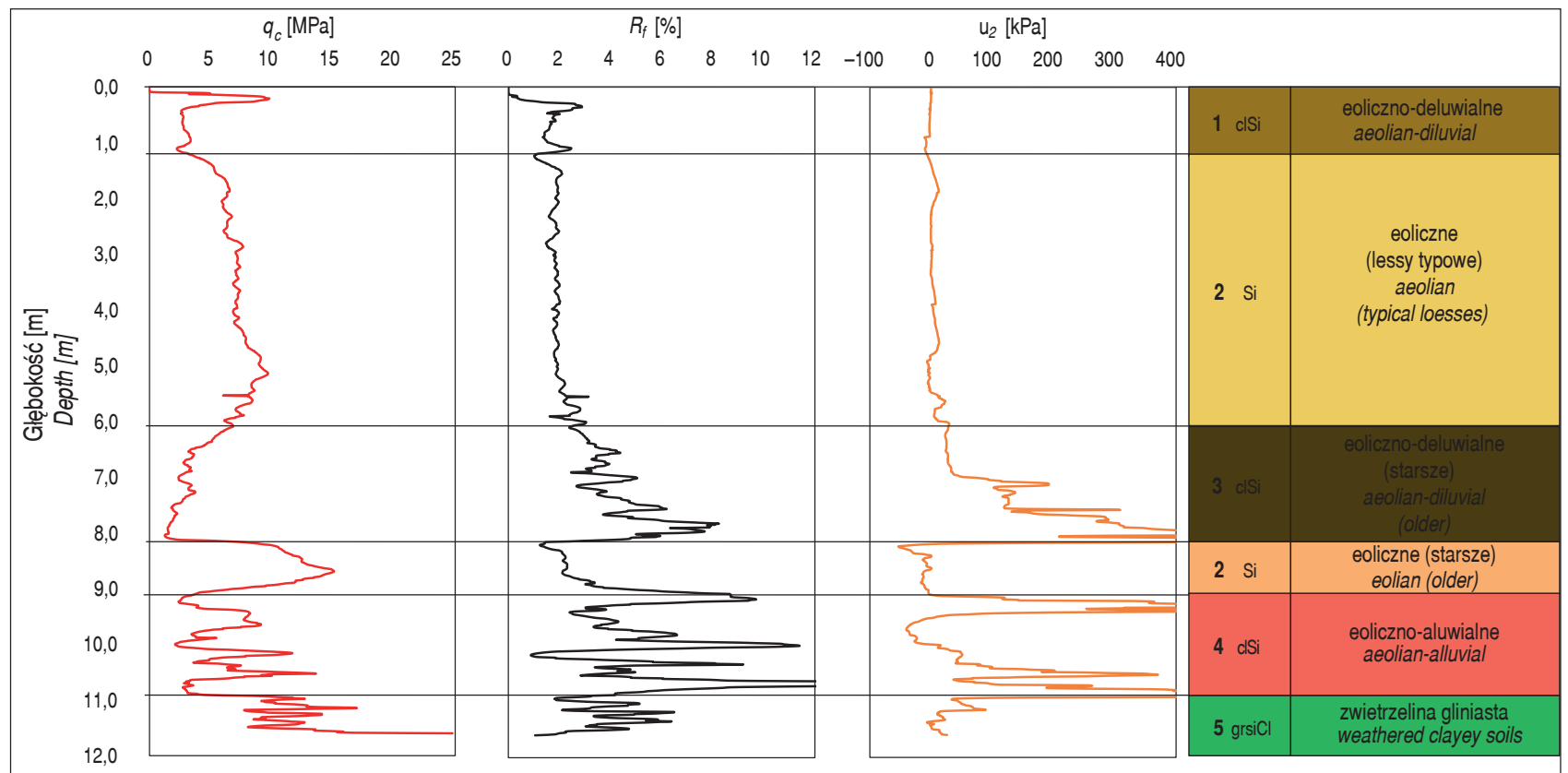

Ryc. 5. Typowe wykresy sondowania CPTU w lessach lubelskich: $q_{\mathrm{C}}-$ opór stożka, $R_{\mathrm{f}}-$ współczynnik tarcia, $u_{2}-$ ciśnienie wody w porach

Fig. 5. Typical CPTU profile in the Lublin loess: $q_{\mathrm{C}}$ - cone resistance, $R_{\mathrm{f}}$-friction ratio, $u_{2}$ - pore water pressure 
tej facji często wartości $q_{\mathrm{c}}$ są znacznie wyższe niż w lessach eolicznych młodszych), ,,powrotem” $R_{\mathrm{f}}$ do poziomu ok. $2 \%$ oraz spadkiem wartości $u_{2}$. Najgłębiej występujące $(9,0$ $11,0 \mathrm{~m}$ p.p.t.) lessy eoliczno-aluwialne charakteryzują się spadkiem wartości $q_{\mathrm{c}}$ oraz wzrostem $R_{\mathrm{f}}$ i $u_{2}$, ponadto jest zauważalna ich znaczna zmienność i niejednorodność. Zaprezentowany przykład wybrano jako reprezentatywny, ponieważ zawiera każdą $\mathrm{z}$ analizowanych facji, co jednak nie jest regułą, natomiast rozkład parametrów sondowania co do zasady jest podobny w każdej części Lublina. Analiza parametrów CPTU jest pomocna przy identyfikacji facjalnej lessów, a więc łączenia ich w warstwy geotechniczne charakteryzujące się zbliżonym zachowaniem.

Analiza 1136 sondowań CPT, CPTU oraz CPTM o sumarycznej długości ok. 8385 m.b. wykonanych w Lublinie w latach 2015-2020 (Nepelski, Lal, 2021) pozwoliła na scharakteryzowanie poszczególnych facji lessowych oraz ocenę ich przydatności jako podłoża budowlanego. Analiza ta jest kontynuacją wcześniej publikowanych prac (Nepelski, Rudko, 2018; Nepelski, 2020), rozszerzoną o kolejne dane. Powiększony zbiór danych nie wpłynął na główne ustalenia z wcześniejszych prac, lecz uwiarygodnił wyniki w ujęciu statystycznym, a także pozwolił na rozdzielenie wyników ze względu na grupy facjalne oraz częściowo rodzaj zastosowanego stożka. Na rycinie 6 przedstawiono względy rozkład uzyskiwanych wartości $q_{\mathrm{c}}$ dla poszczególnych facji, natomiast na rycinie 7 zbiorczo zestawiono wartości $q_{\mathrm{c}}$ uzyskane dla podłoża lessowego z rozdzieleniem na poszczególne facje. $Z$ analizy wynika, że charakteryzują się one zróżnicowanymi oporami stożka $q_{\mathrm{c}}$, a ich charakterystyczne parametry sondowania CPTU zestawiono $\mathrm{w}$ tabeli 2, natomiast szczegółowa analiza ich wyników zawarta jest w pracy Nepelskiego i Lal (2021). Wyniki uzyskiwane różnymi rodzajami stożków mogą się różnić. Korelacje pomiędzy podstawowymi parametrami otrzymywanymi stożkiem elektrycznym i mechanicznym w lessach przedstawiono w pracy Nepelskiego i in. (2019). Opory stożka $q_{\mathrm{c}}$ przyjmują zbliżone wartości przy wykorzystaniu obydwu stożków, natomiast tarcie na tulei ciernej $f_{\mathrm{s}}$ pomierzone
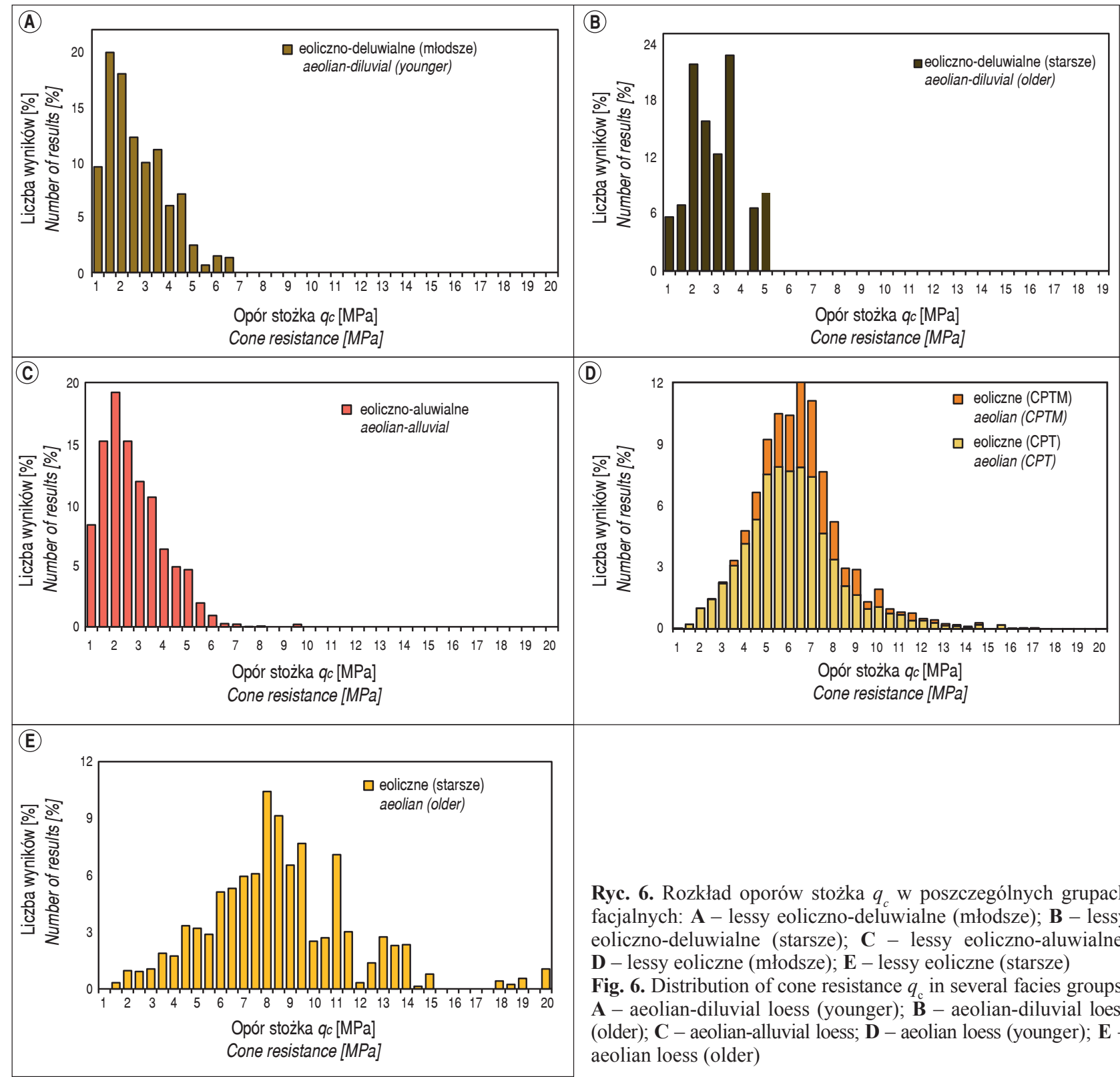

Ryc. 6. Rozkład oporów stożka $q$ w poszczególnych grupach facjalnych: A - lessy eoliczno-deluwialne (młodsze); B - lessy eoliczno-deluwialne (starsze); C - lessy eoliczno-aluwialne; D - lessy eoliczne (młodsze); $\mathbf{E}$ - lessy eoliczne (starsze)

Fig. 6. Distribution of cone resistance $q_{\mathrm{c}}$ in several facies groups: $\mathbf{A}$ - aeolian-diluvial loess (younger); $\mathbf{B}$ - aeolian-diluvial loess (older); $\mathbf{C}$ - aeolian-alluvial loess; $\mathbf{D}$ - aeolian loess (younger); $\mathbf{E}$ aeolian loess (older) 


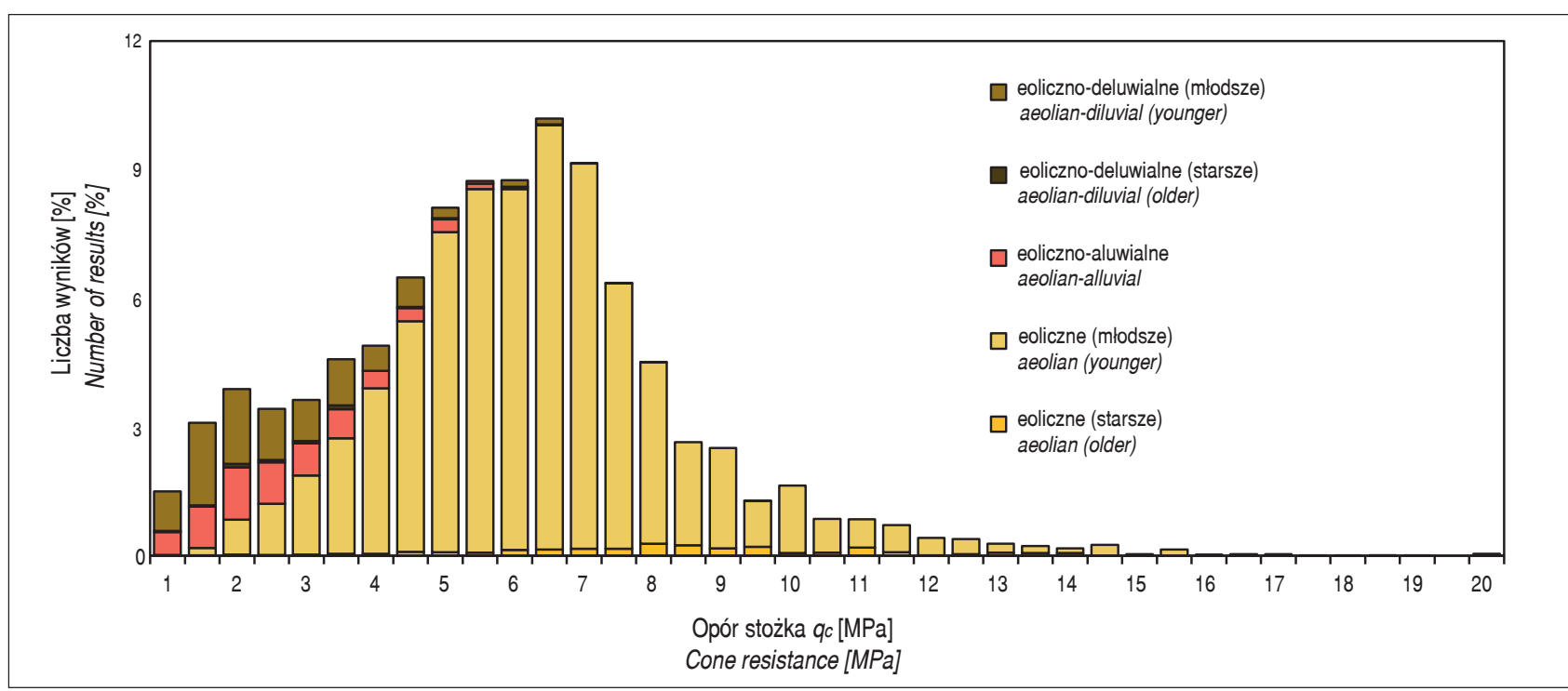

Ryc. 7. Zbiorczy rozkład oporów stożka $q_{\mathrm{c}}$ w lessach Lublina

Fig. 7. Summary distribution of cone resistance $q_{\mathrm{c}}$ in the Lublin loess

stożkiem mechanicznym jest ponad dwukrotnie wyższe niż pomiar stożkiem elektrycznym.

Sondowania statyczne często służą do oceny podstawowych parametrów klasyfikacyjnych gruntu, tj. stopnia plastyczności $I_{\mathrm{L}}$ lub zagęszczenia $I_{\mathrm{D}}$. Lessy to głównie utwory pylaste, które są gruntami przejściowymi z pogranicza spoistych i niespoistych, stąd też żaden z tych parametrów zasadniczo nie jest właściwy do ich opisu, pomimo że regularnie w Polsce jest stosowany. Zgodnie z ustaleniami autora (Nepelski i in., 2016) przy interpretacji stopnia plastyczności w lessach graniczna wartość $I_{\mathrm{L}}=0,00$ występuje przy oporach stożka $q_{\mathrm{c}}=4,0 \div 4,5 \mathrm{MPa}$. Nie jest to sztywna granica i zdarzają się zarówno lessy zwarte o $q_{\mathrm{c}}<3,0 \mathrm{MPa}$ (głównie eoliczne, położone płytko - te mają tendencję do osiadania zapadowego), jak również twardoplastyczne o $q_{\mathrm{c}}>7,0 \mathrm{MPa}$ (eoliczne starsze, występujące głębiej).
Z wykresu przedstawionego na rycinie 7 wynika, że większość lessów lubelskich charakteryzuje się wartościami $q_{\mathrm{c}}>4,5 \mathrm{MPa}$. Świadczy to o tym, że w obrębie lessów zwartych występuje znaczne zróżnicowanie $q_{\mathrm{c}}$, a więc także sztywności podłoża. Biorąc pod uwagę ewidentne zróżnicowanie sztywności lessów zwartych oraz możliwość występowania uplastycznionych lessów starszych o wysokich oporach stożka, zdaniem autora zdecydowanie bardziej poprawne jest wydzielanie warstw geotechnicznych $\mathrm{z} q_{\mathrm{c}}$ jako parametrem wiodącym, niż $I_{\mathrm{L}}$, jak to jest powszechnie stosowane w Polsce. Stopień plastyczności, o ile w ogóle ma być wyznaczany dla lessów, to należy traktować jako parametr drugorzędny, jedynie poglądowy, na co zwracali uwagę również Frankowski i Pietrzykowski (2017), określając „błędem dokumentacyjnym” przypisywanie stopnia plastyczności pyłom lessowym.

Tab. 2. Charakterystyczne wartości parametrów sondowań statycznych dla poszczególnych facji Table 2. Characteristic values of CPTU parameters for several facies groups

\begin{tabular}{|c|c|c|c|}
\hline $\begin{array}{l}\text { Grupa facjalna } \\
\text { Facies group }\end{array}$ & $\begin{array}{l}q_{c} / \sigma^{*} \\
{[\mathrm{MPa}]}\end{array}$ & $\begin{array}{c}R_{f} / \sigma^{*} \\
{[\%]}\end{array}$ & $u_{2}$ \\
\hline $\begin{array}{l}\text { Eoliczno-deluwialna (młodsza) } \\
\text { Aeolian-diluvial (younger) }\end{array}$ & $2,88 / 1,29$ & $3,77 / 1,65$ & $\begin{array}{l}\text { bliskie zeru } \\
\text { close to zero }\end{array}$ \\
\hline $\begin{array}{l}\text { Eoliczno-deluwialna (starsza) } \\
\text { Aeolian-diluvial (older) }\end{array}$ & $3,11 / 1,13$ & 4,09 / 1,20 & $>0 \mathrm{kPa}$ \\
\hline $\begin{array}{l}\text { Eoliczno-aluwialna } \\
\text { Aeolian-alluvial }\end{array}$ & $2,98 / 1,27$ & 4,68 / 1,62 & $>0 \mathrm{kPa}$ \\
\hline $\begin{array}{l}\text { Eoliczna (stożek mechaniczny) } \\
\text { Aeolian (mechanical cone) }\end{array}$ & $7,23 / 1,81$ & $4,48 / 1,12$ & - \\
\hline $\begin{array}{l}\text { Eoliczna (stożek elektryczny) } \\
\text { Aeolian (electric cone) }\end{array}$ & $6,48 / 2,20$ & $2,44 / 0,65$ & \multirow{2}{*}{$\begin{array}{l}\text { bliskie zeru lub nieznacznie ujemne } \\
\text { close to zero or slightly negative }\end{array}$} \\
\hline $\begin{array}{l}\text { Eoliczna (starsza) } \\
\text { Aeolian (older) }\end{array}$ & $8,87 / 3,12$ & $2,82, / 0,86$ & \\
\hline
\end{tabular}

$q_{\mathrm{C}}$ - opór stożka, $R_{\mathrm{f}}$ - współczynnik tarcia, $u_{2}$ - ciśnienie wody w porach, * wartości średnie / odchylenie standardowe

$q_{\mathrm{C}}$-cone resistance, $R_{\mathrm{f}}$-friction ratio, $u_{2}$-pore water pressure, ${ }^{*}$ average value / standard deviation 
Sondowania statyczne są podstawą do interpretacji modułu ściśliwości. Najczęściej wykorzystywane są formuły Sanglerata (1972):

$$
M=\alpha_{m} q_{c}
$$

gdzie:

$q_{\mathrm{c}}$ - opór stożka

$\alpha_{\mathrm{m}}$ - współczynnik empiryczny,

lub Senneseta i in. (1982):

$$
M=\alpha_{m}\left(q_{\mathrm{t}}-\sigma_{\mathrm{v} 0}\right)
$$

gdzie:

$q_{\mathrm{t}}$ - opór stożka netto

$\sigma_{\mathrm{v} 0}$ - naprężenia geostatyczne $\mathrm{w}$ poziomie pomiaru.

Współczynnik empiryczny $\alpha$ w praktyce jest przyjmowanym w szerokim zakresie $(1 \div 15)$ w zależności od rodzaju gruntu, historii jego obciążenia oraz zakresu odkształceń do jakiego jest interpretowany (Sanglerat, 1972; Ciloglu $\mathrm{i}$ in., 2014).

Dla lessów z okolic Łańcuta Młynarek i in. (2015a, b) przyjmowali, zgodnie z wytycznymi Kulhawego i Mayna (1990), wzór [2] ze współczynnikiem $\alpha_{m}=8,25$.

Dla lessów z Kazimierza Dolnego Frankowski i Pietrzykowski (2017) wyprowadzili dla formuły [1] współczynnik $\alpha_{m}=2,5$ skalibrowany $\mathrm{w}$ odniesieniu do modułu ściśliwości wyznaczonego z laboratoryjnych badań edometrycznych. Badania własne autora potwierdzają zgodność tak szacowanych wartości modułów ściśliwości z modułami edometrycznymi z badań laboratoryjnych, jednak należy mieć na uwadze, że badania edometryczne odzwierciedlają pracę podłoża w zakresie dużych odkształceń. Stosowanie w obliczeniach osiadań fundamentów parametrów uzyskanych bezpośrednio z badań edometrycznych skutkuje otrzymaniem obliczeniowych osiadań znacznie przekraczających tych pomierzonych geodezyjnie. Problem ten był wielokrotnie poruszany w literaturze (Borowczyk, Frankowski, 1979; Szulborski, Wysokiński, 2004; Truty, 2008; Godlewski, Szczepański, 2011; Wiłun, 2013; Nepelski, 2020). W związku z powyższym do wyznaczania modułu ściśliwości z sondowań statycznych $M_{\mathrm{CPT}}$ autor proponuje stosować formułę [1] ze współczynnikiem $\alpha_{m}=6,0$. Współczynnik ten został przez autora skalibrowany z pomiarami osiadań rzeczywistych budynków posadowionych na lessach w Lublinie i odpowiada pracy gruntu przy odkształceniach rzędu $0,1 \%$, czyli występujących pod typowymi fundamentami. Tak wyznaczona wartość powinna być $\mathrm{z}$ reguły mniejsza o ok. $10 \div 20 \%$ od modułu dylatometrycznego $M_{\text {DMT }}$ (Mayne, 2001; Amoroso i in., 2013; Monaco i in., 2014; Nepelski, 2020, 2021).

\section{BADANIA DYLATOMETREM PLASKIM DMT/SDMT}

Testy dylatometryczne DMT są bardzo dobrym narzędziem do oceny parametrów odkształceniowych i historii gruntu. Badania wykonywane są in situ, w stanie naturalnych naprężeń, a prawidłowość uzyskiwanych modułów ściśliwości była wielokrotnie potwierdzana pomiarami rzeczywistych osiadań (Marchetti, 2015; Godlewski, 2018). Poniżej przedstawiono analizy wyników 27 testów przeprowadzonych w różnych częściach Lublina, z czego w 17 wykonano również pomiar sejsmiczny (SDMT). Analizo- wane testy DMT i SDMT wykonywano w węzłach badawczych w bezpośrednim sąsiedztwie ok. 2-3 m od sondowań CPT/CPTU. Łączenie testów DMT/SDMT z CPT/CPTU dostarcza cennych danych i tego typu analizy były przeprowadzane wielokrotnie (Marchetti, 1980; Robertson, 2009a; Mayne, 2016), również dla gruntów lessowych (Młynarek i in., 2015a; Nepelski, 2021).

Wskaźnik naprężenia bocznego $K_{\mathrm{D}}$ uzyskiwany z badania DMT jest podstawą do oceny historii gruntu oraz wyznaczenia wskaźnika prekonsolidacji OCR. Lessy lubelskie są z natury gruntami normalnie skonsolidowanymi (NC), jednak w strefie przypowierzchniowej wyniki wskazują na częściową prekonsolidację (OC). W większości testów w stropowych partiach, które obejmują głównie lessy eoliczno-deluwialne oraz częściowo typowe lessy eoliczne, zauważalny jest wzrost wskaźnika $K_{D}$. Jest to zjawisko typowe i może to być spowodowane np. nadkładem gruntu, który w przeszłości znajdował się na danym terenie, lub innymi obciążeniami występującymi czasowo na powierzchni terenu. Wzrost wskaźnika $K_{D}$ w pyłach przez niektórych badaczy łączony jest również z pseudoprekonsolidacją, wynikającą m.in. z cementacji (Marchetti, 2015; Radaszewski, Stefaniak, 2017). Zdaniem autora wzrost wskaźnika $K_{\mathrm{D}}$ wynika $\mathrm{w}$ większej mierze z pseudoprekonsolidacji niż z prekonsolidacji właściwej.

Wskaźnik prekonsolidacji $O C R$ jest parametrem interpretowanym. Do oceny $O C R$ powszechnie jest stosowana pierwotna formuła Marchettiego (1980):

$$
O C R=0,5 K_{D}^{1,56}
$$

Odnosi się ona jednak jedynie do gruntów drobnoziarnistych o wskaźniku materiałowym $I_{\mathrm{D}} \leq 1,2$. Badane lessy są głównie pylaste i charakteryzują się w większości wskaźnikiem $I_{\mathrm{D}}$ bliskim 1,8 , co wskazuje, że charakter ich pracy bardziej odpowiada gruntom piaszczystym, dla których wyznaczenie $O C R$ jest trudniejszym zagadnieniem. Zgodnie z początkowymi badaniami Marchettiego i Crappsa (1981) dla gruntów o $I_{\mathrm{D}}>1,2$ wskaźnik prekonsolidacji OCR można było wyznaczać z zależności:

$$
\begin{aligned}
O C R & =0,67 K_{D}^{1,91}, \text { dla } I_{\mathrm{D}}>2,0 \\
\text { gdzie: } \quad m & =m K_{D}{ }^{n} \text {, dla } 1,2<I_{\mathrm{D}}>2,0 \\
& =0,5+0,17\left(\frac{I_{D}-1,2}{0,8}\right) \\
n & =1,56+0,35\left(\frac{I_{D}-1,2}{0,8}\right)
\end{aligned}
$$

Dodatkowe badania i liczne rozbieżności ograniczyły jednak stosowalność formuły i obecnie rzadko jest ona wykorzystywana. Ponieważ lessy pylaste w zachowaniu zbliżone są do piasków, to do oceny $O C R$ można wykorzystać formułę Monaco i in. (2014), łącząc wyniki testów DMT i CPTU wykonanych w niewielkiej odległości:

$O C R=0,0344\left(M_{\mathrm{DMT}} / q_{\mathrm{t}}\right)^{2}-0,4174 M_{\mathrm{DMT}} / q_{\mathrm{t}}+2,2914$

Dla pyłów są stosowane również formuły Lunne i in. (1997) w formie:

$$
O C R=K_{D}^{1,17}
$$

oraz Simonini i in. (2007):

$$
O C R=0,66 K_{D}^{1,17}
$$


Po analizie rozkładu $O C R$ na głębokości, wyznaczonego różnymi formułami dla wszystkich punktów badawczych, uznano, że ocena prekonsolidacji formułami [4] i [5] skutkuje znacznie zawyżonymi wskaźnikami $O C R$, co potwierdza ograniczoną stosowalności tej formuły. Dlatego taką zależność uznano za nieodpowiednią dla pylastych gruntów lessowych. Dużo bardziej wiarygodne wyniki uzyskuje się natomiast formułami [7] i [8]. Zdaniem autora dla lessów powinna zostać wyznaczona odrębna zależność, lecz do czasu wyznaczenia właściwej formuły, można stosować wzór [7]. Rozkład $q_{\mathrm{t}}-M_{\mathrm{DMT}}-K_{\mathrm{D}}$ oraz porównanie wskaźnika $O C R$ wyznaczonego różnymi formułami wraz z teoretycznym rozkładem $O C R$ dla naprężenia prekonsolidacyjnego $100 \mathrm{kPa}$ dla przykładowego punktu 5 podano na rycinie $8 \mathrm{a}-\mathrm{b}$. Poglądowe, zbiorcze zestawienie rozkładu $O C R$ na głębokości dla wszystkich punktów szacowanych formułą [7] przedstawiono na rycinie $8 \mathrm{c}$.

Wyższy wskaźnik $K_{D}$ w górnych partiach w wykonanych testach jest połączony z wyższą wartością modułu dylatometrycznego $M_{\mathrm{DMT}}$. Jednak dla tej strefy opory $q_{\mathrm{c}}$ z sondowań CPT są zazwyczaj niskie, a często nawet dużo niższe niż w głębszych partiach podłoża, w związku z tym również moduł dylatometryczny $M_{\mathrm{DMT}}$ znacząco przewyższa moduł ściśliwości $M_{\mathrm{CPT}}$. Można to wiązać z tym, że podłoże jest częściowo skonsolidowane w strefie przypowierzchniowej, a moduł dylatometryczny $M_{\text {DMT }}$ przy wyższych wartościach $K_{\mathrm{D}}$ opisuje grunt prekonsolidowanych (OC). W związku z tym, w prowadzonych analizach wartości $M_{\mathrm{DMT}}$ rozdzielono nie tylko ze względu na grupy facjalne, lecz także na wartość wskaźnika $K_{\mathrm{D}}$. Przyjęto, że $M_{\text {DMT }}$ przy $K_{\mathrm{D}} \leq 4$ (odpowiadające zgodnie z formułą [7] $O C R<1,5$ ) opisuje grunt normalnie skonsolidowany (NC) lub lekko prekonsolidowany (LOC), natomiast $M_{\mathrm{DMT}}$ dla $K_{\mathrm{D}}>4(O C R>1,5)$ odzwierciedla ściśliwość jak dla gruntów prekonsolidowanych (OC). Zestawienie $M_{\mathrm{DMT}}-q_{\mathrm{t}}$ dla poszczególnych facji oraz zbiorcze dla wszystkich pomiarów przedstawiono na rycinie 9 , a na rycinie 10 zestawiono rozkład wartość $M_{\text {DMT }}$ oraz $K_{\mathrm{D}}$. Charakterystyczne parametry testów DMT/SDMT dla poszczególnych facji zebrano w tabeli 3 .

Siedemnaście testów dylatometrycznych wykonano z sejsmicznym pomiarem prędkości rozchodzenia się fali poprzecznej V (SDMT). Wyniki te były podstawą do wyznaczenia początkowego modułu ścinania $\mathrm{G}_{0}$, który obliczono z zależności:

$$
G_{0}=\rho V_{\mathrm{s}}^{2}
$$

W literaturze są wyprowadzane zależności $G_{0} / M_{\text {DMT }}$ w połączeniu ze wskaźnikiem $K_{\mathrm{D}}$ (Marchetti i in., 2008; Marchetti, 2015; Godlewski, 2018). Na rycinie 11 pokazano rozkład $G_{0} / M_{\mathrm{DMT}}$ od $K_{\mathrm{D}}$ na tle zależności wyznaczonych Ryc. 8. Ocena prekonsolidacji lessów: A - porównanie parametrów testów CPTU C - zbiorcze zestawienie rozkładów $O C R$ na głębokości dla wszystkich testów DMT/SDMT

Fig. 8. Evaluation of loess preconsolidation: $\mathbf{A}$ - comparison of CPTU and DMT test parameters; B - comparison of the OCR obtained from the $K_{\mathrm{D}}$ index with different formulas; $\mathbf{C}$ - summary of $O C R$ distributions at a depth for all DMT/SDMT tests
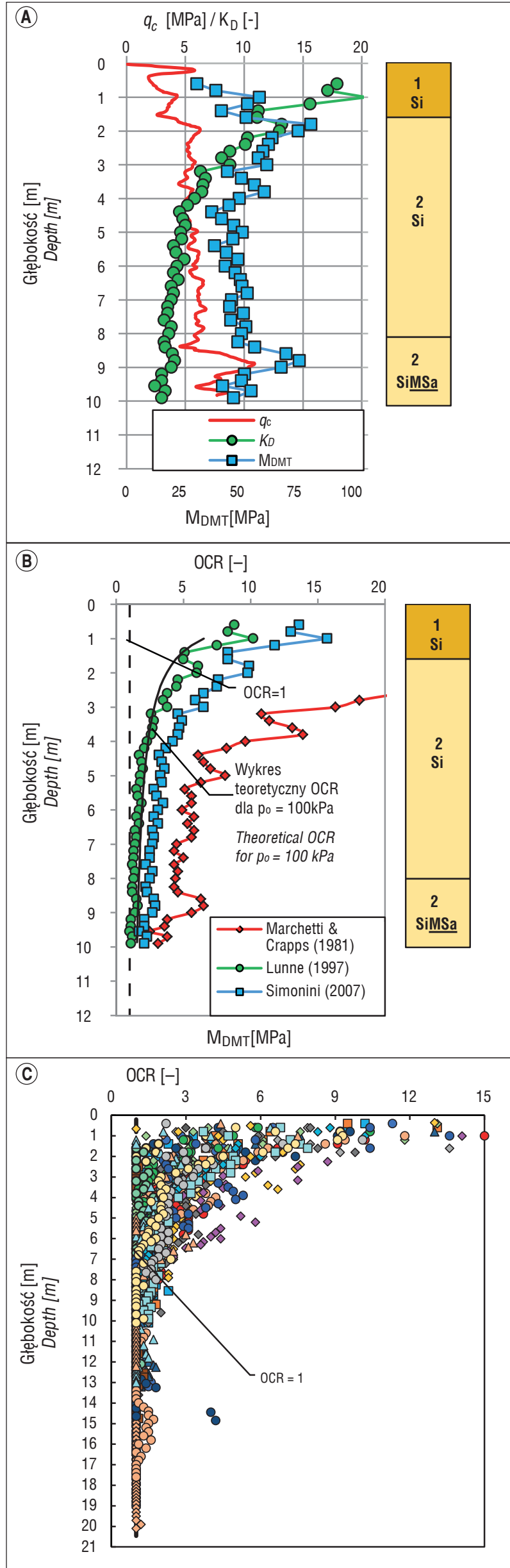
Tab. 3. Charakterystyczne wartości parametrów sondowań statycznych dla poszczególnych facji

Table 3. Characteristic values of CPTU parameters for several facies groups

\begin{tabular}{|c|c|c|c|}
\hline \multirow{2}{*}{$\begin{array}{c}\text { Parametr } \\
\text { Parameter }\end{array}$} & \multicolumn{3}{|c|}{$\begin{array}{c}\text { Grupa facjalna } \\
\text { Facies group }\end{array}$} \\
\cline { 2 - 4 } & $\begin{array}{c}\text { eoliczno-deluwialna* } \\
\text { aeolian-diluvial }\end{array}$ & $\begin{array}{c}\text { eoliczna* } \\
\text { aeolian }\end{array}$ & $\begin{array}{c}\text { eoliczno-aluwialna* } \\
\text { aeolian-alluvial }\end{array}$ \\
\hline$K_{\mathrm{D}}$ & $11,7 / 7,4$ & $5,5 / 4,2$ & $2,7 / 2,4$ \\
\hline$M_{\mathrm{DMT}}\left(K_{\mathrm{D}} \leq 4\right)$ & $11,9 / 6,9$ & $36,6 / 35,9$ & $22,8 / 15,5$ \\
\hline$M_{\mathrm{DMT}}\left(K_{\mathrm{D}}>4\right)$ & $40,4 / 30,8$ & $62,8 / 57,6$ & $36,4 / 32,1$ \\
\hline$q_{\mathrm{t}}$ & $3,1 / 2,9$ & $6,5 / 6,2$ & $4,5 / 2,9$ \\
\hline$G_{0}$ & $60,4 / 61,3$ & $115,3 / 114,2$ & $155,6 / 156,6$ \\
\hline
\end{tabular}

$K_{\mathrm{D}}$ - wskaźnik parcia bocznego, $M_{\mathrm{DMT}}-$ moduł ściśliwości z badania DMT, $q_{\mathrm{t}}$ - całkowity opór stożka z badania CPTU, $G_{0}-$ początkowy moduł ścinania, * wartość średnia / mediana

$K_{\mathrm{D}}$ - horizontal stress index, $M_{\mathrm{DMT}}$ - constrained modulus from DMT test, $q_{\mathrm{t}}$ - total cone resistance from CPTU test, $G_{0}-$ maximum shear modulus, *average value / median
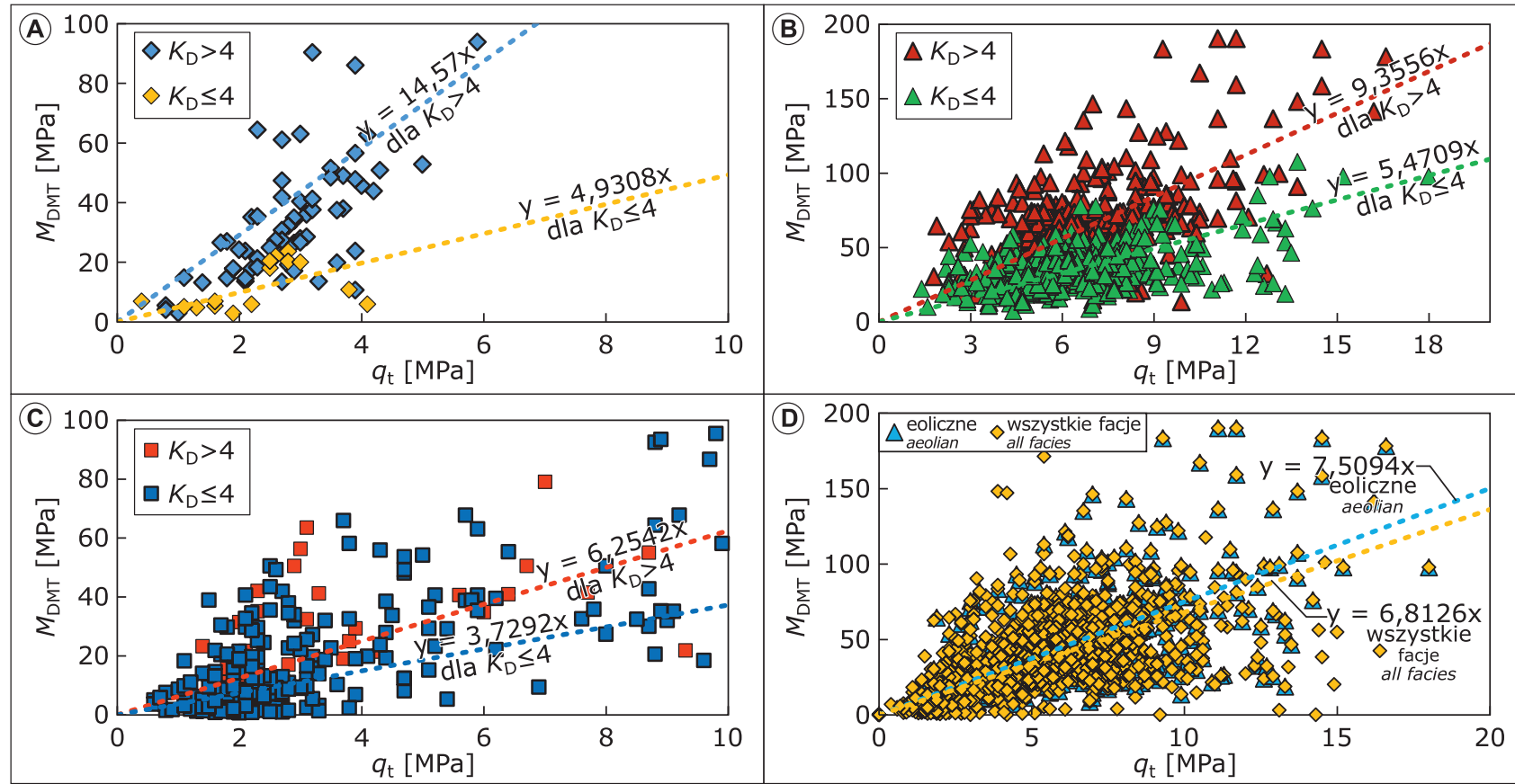

Ryc. 9. Zależność $\mathrm{M}_{\mathrm{DMT}}-\mathrm{q}_{\mathrm{t}}$ dla poszczególnych grup facjalnych: A - eoliczno-deluwialnej, B - eolicznej, C - eoliczno-aluwialnej, D - zbiorczo dla wszystkich lessów

Fig. 9. $M_{D M T}-q_{t}$ relationship for several facies groups: $\mathbf{A}$ - aeolian-diluvial, $\mathbf{B}$ - aeolian, $\mathbf{C}$ - aeolian-alluvial, $\mathbf{D}$ - summary for all loess
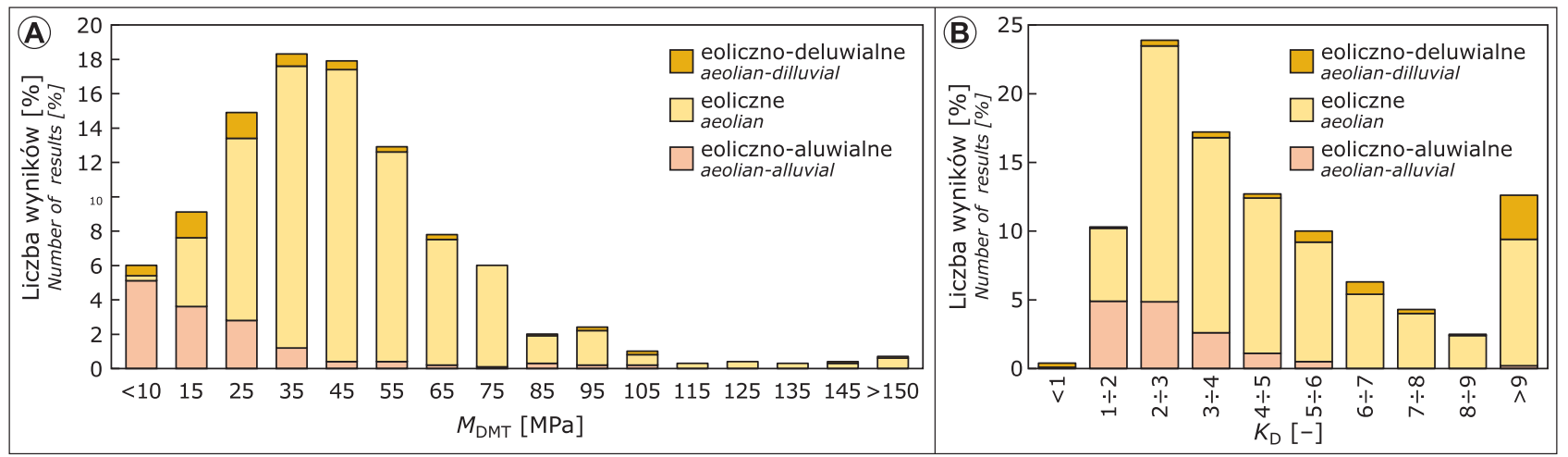

Ryc. 10. Parametry testów DMT dla lessów lubelskich z podziałem na grupy facjalne: $\mathbf{A}-\operatorname{rozk}$ ad $M_{D M T}, \mathbf{B}-\operatorname{rozkład} K_{D}$

Fig. 10. Parameters of DMT tests for the Lublin loess with division into facies group: $\mathbf{A}-\mathrm{M}_{D M T}$ distribution, $\mathbf{B}-\mathrm{K}_{\mathrm{D}}$ distribution 
przez Marchettiego i in. (2008). Uzyskane wyniki wpisują się w trend Marchettiego dla gruntów z pograniczna piaszczystych i pylastych. Dużo wyższe wartości wskaźnika $G_{0} / M_{\text {DMT }}$ uzyskano dla facji eoliczno-aluwialnej, co wynika z głębokości jej zalegania. Grunty te zazwyczaj występują od kilku do kilkunastu metrów poniżej terenu, przez co pracują przy większych naprężeniach in situ, a co za tym idzie, początkowy moduł ścinania jest wyższy niż dla facji, które występują płycej.

Analizy testów SDMT i DMT pozwoliły na sformowanie następujących wniosków:

1. Więcej wyników $\mathrm{M}_{\mathrm{DMT}}$ dla $\mathrm{K}_{\mathrm{D}}>4$ otrzymano w grupach facjalnych występujących płycej.

2. Dla grup facjalnych występujących płycej uwidacznia się znacznie większa dysproporcja pomiędzy modułami $M_{\text {DMT }}$ dla różnych zakresów $K_{\mathrm{D}}$.

3. W ujęciu ogólnym uzyskano zależności $M_{\mathrm{DMT}}=6,8 q_{\mathrm{t}}$ dla wszystkich wyników oraz $M_{\mathrm{DMT}}=5 q_{\mathrm{t}}$ dla najpowszechniej występującej facji eolicznej. Przy stosowanej interpretacji $M_{\mathrm{CPT}}$, odpowiada to $M_{\mathrm{DMT}}=1,13 \div 1,25 M_{\mathrm{CPT}}$, co jest zbieżne z wcześniej poczynionymi założeniami wyznaczania modułu ściśliwości z sondowań statycznych.

\section{BADANIA PREJSOMETREM MENARDA (PMT)}

Badania presjometrem Menarda (PMT) to swego rodzaju próbne obciążenie gruntu w małej skali. Podstawowe parametry uzyskiwane $\mathrm{z}$ badania to moduł presjometryczny $E_{\mathrm{M}}$, naprężenie graniczne $p_{1}$ oraz naprężenie pełzania $p_{\mathrm{f}^{*}}$ Testy wykonuje się w przygotowanym wcześniej otworze o średnicy minimalnie większej od sondy w kształcie walca. W prezentowanych badaniach wykorzystywano sondę presjometryczną typu BX $60 \mathrm{~mm}$, a badania wykonywano techniką poprzedzoną wierceniem, tzw. PDP (Pre Drilling Pressumeter Test). Łącznie w lessach wykonano 36 pomiarów na pięciu poletkach badawczych. W każdym przypadku badanie wykonywano w bezpośrednim sąsiedztwie sondowania CPT, a w trzech przypadkach również z pomiarami DMT lub SDMT. Ze względu na stosunkowo niewielki zbiór danych, należy je traktować jako wstępne. Zdaniem autora najbardziej wartościowym parametrem są naprężenia graniczne $p_{1}$, które służą bezpośrednio do wyznaczania nośności gruntu. W klasycznych metodach analitycznych do wyznaczania nośności podłoża wykorzystuje się parametry wytrzymałościowe: kąt tarcia wewnętrznego i spójność lub wytrzymałość na ścinanie w warunkach bez odpływu. Wobec trudności i czasochłonności przy prawidłowym wyznaczaniu efektywnych parametrów podłoża w laboratorium, półempiryczna metoda szacowania nośności gruntu z pomiarów PMT jest rozwiązaniem zarówno szybszym, jak i ekonomiczniejszym. Obecnie badania presjometryczne są nielicznie wykonywane w Polsce, większą popularnością cieszyły się w przeszłości. Badania na lessach lubelskich były prowadzone m.in. przez Borowczyka i Frankowskiego $(1977,1979)$. Wedle ich badań naprężenia graniczne $p_{1} \mathrm{w}$ zależności od typu lessu wahają się w szerokim zakresie 0,21-1,36 MPa, średnio ok. 0,80 MPa. Norma PN-B-04452 dla lessów wskazuje wartości $p_{1} \mathrm{w}$ zakresie 0,20-1,24 MPa, ze średnią 0,75 MPa. Tarnawski (2007), będący autorytetem w dziedzinie badań presjometrycznych w Polsce, podaje typowe wartości dla gruntów spoistych w stanie półzwartym $p_{1}$ w zakresie $0,8-1,6 \mathrm{MPa}$, a w stanie zwartym - powyżej 1,6 MPa. Z badań autora uzyskano wartości w zakresie 0,21-1,43 $\mathrm{MPa}$, ze średnią

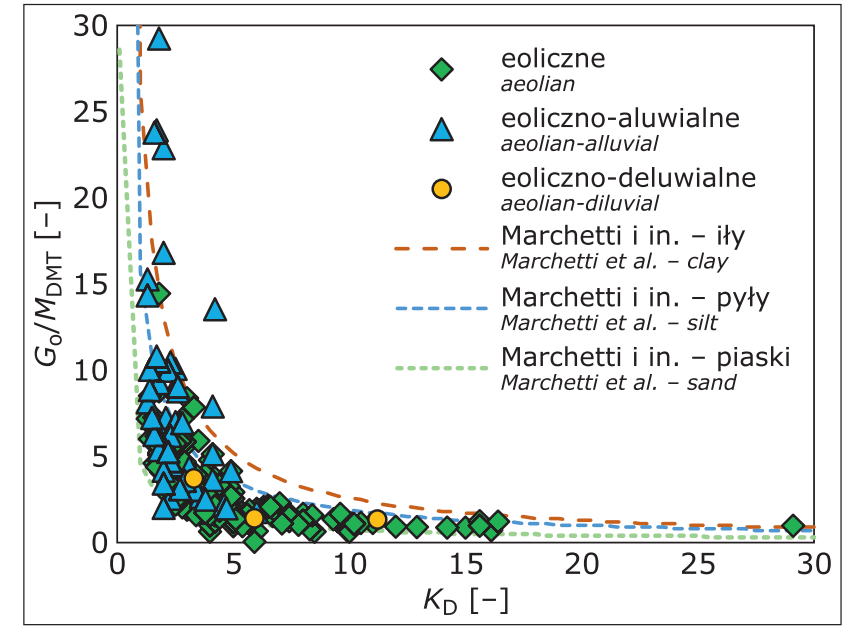

Ryc. 11. Rozkład wskaźnika $G_{0} / M_{\mathrm{DMT}}-K_{\mathrm{D}}$ dla różnych typów lessów

Fig. 11. Distribution of the $G_{0} / M_{\mathrm{DMT}}-K_{\mathrm{D}}$ index for various types of loess

0,90 MPa, co wpisuje się w zakres przytoczonych danych. Wedle Borowczyka i Frankowskiego (1977) badania presjometryczne mogą służyć także do oceny zapadowości lessów. Kryterium zapadowości określa się na podstawie różnicy naprężeń granicznych $p_{1}$ i pełzania $p_{\mathrm{f}}$, przybiera ono formę:

$$
p_{1}-p_{\mathrm{f}} \leq 0,21 \mathrm{MPa}
$$

$\mathrm{Na}$ wykresie (ryc. 12) przedstawiono różnicę wartości $p_{1}-p_{\mathrm{f}}$ wyznaczone dla wykonanych badan. Tylko jeden wynik, dla pomiaru na głębokości $2 \mathrm{~m}$ p.p.t., wskazuje na

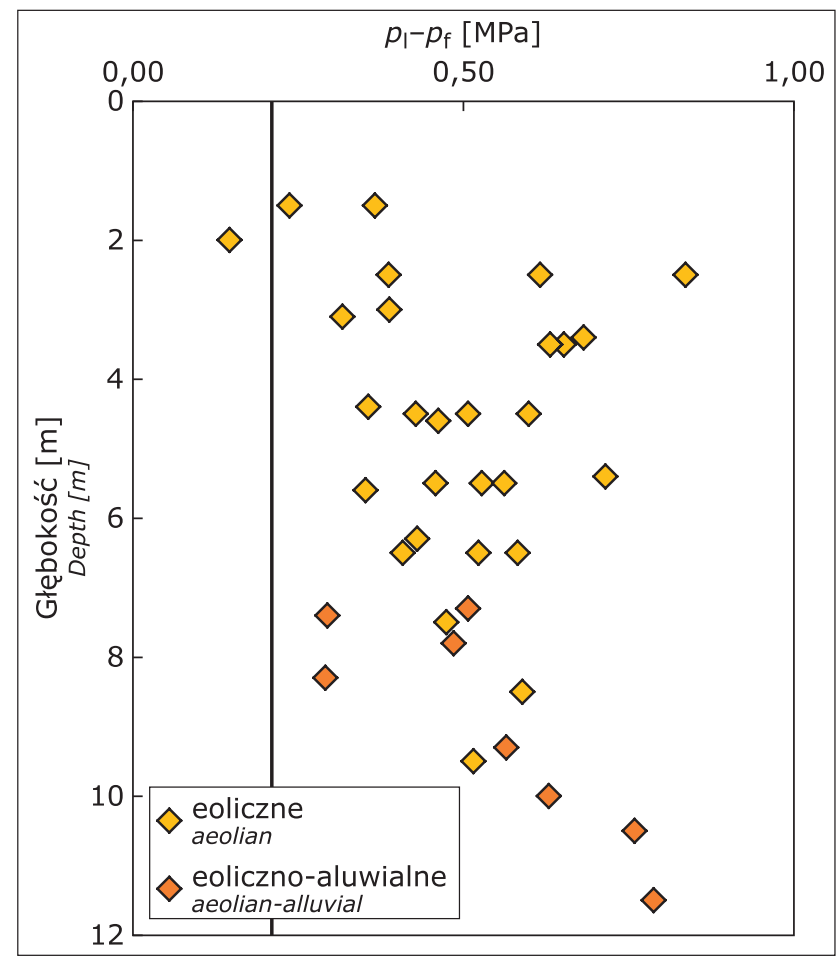

Ryc. 12. Zestawienie wartości $p_{1}-p_{\mathrm{f}} \mathrm{W}$ zależności od głębokości Fig. 12. Relationship of $p_{1}-p_{\mathrm{f}}$ values depending on the depth 
charakter zapadowy lessów, a jeden wynik, na głębokości 1,5 m p.p.t., jest bliski granicy 0,21 $\mathrm{MPa}$.

Na rycinach 13 i 14 przedstawiono zależności $q_{\mathrm{c}}-p$ oraz $q_{\mathrm{c}}-E_{\mathrm{M}}$. Pomimo że baza danych nie jest duża, w obydwu przypadkach uwidacznia się trend pomiędzy parametrami z badań presjometrycznych a oporem stożka $q_{c}$. Po uzupełnieniu zbioru większą liczbą pomiarów możliwe będzie wyprowadzenie wiarygodnych zależności pozwalających m.in. na wyznaczanie nośności podłoża bezpośrednio z oporu stożka $q_{\mathrm{c}}$ przy pewnych stałych założeniach, $\mathrm{np}$. co do wielkości stopy lub poziomu posadowienia.

\section{OCENA PRZYDATNOŚCI PODLOŻA LESSOWEGO DO CELÓW BUDOWLANYCH}

Z prowadzonych przez autora badań wynika, że zdecydowaną większość lessów stanowi facja eoliczna i jej parametry są kluczowe dla posadowienia obiektów budowla- nych. Dla facji tej uzyskuje się najwyższe wartości $q_{c}$ oraz $M_{\text {DMT }}$. Facje eoliczno-deluwialna i eoliczno-aluwialna występują w dużo mniejszym zakresie, a uzyskane zbiory zebranych danych stanowią zbliżony odsetek. Należy mieć na uwadze, że deluwia występują głównie w górnych partiach podłoża, a więc w strefie, którą obejmuje każde wykonywane badanie. Aluwia znajdują się najczęściej w dużo głębszych partiach podłoża, przez co nie wszystkie z wykonanych badań obejmują tę strefę. To samo dotyczy facji eolicznej starszej, której parametry wyznaczono jedynie w części testów. Według autora, objętościowy udział poszczególnych facji w budowie podłoża lessowego w Lublinie rozkłada się następująco: facja eoliczna $75 \div 80 \%$, facja aluwialna $8 \div 15 \%$, facja deluwialna $8 \div 10 \%$.

Często podejmowanym problemem dla lessów jest osiadanie zapadowe (Paj, 2007; Miller i in., 2000; El Howayek i in., 2011; Luo i in., 2018; Lal, 2019). Chociaż zachowanie to jest mocno kojarzone $\mathrm{z}$ tym gruntem,

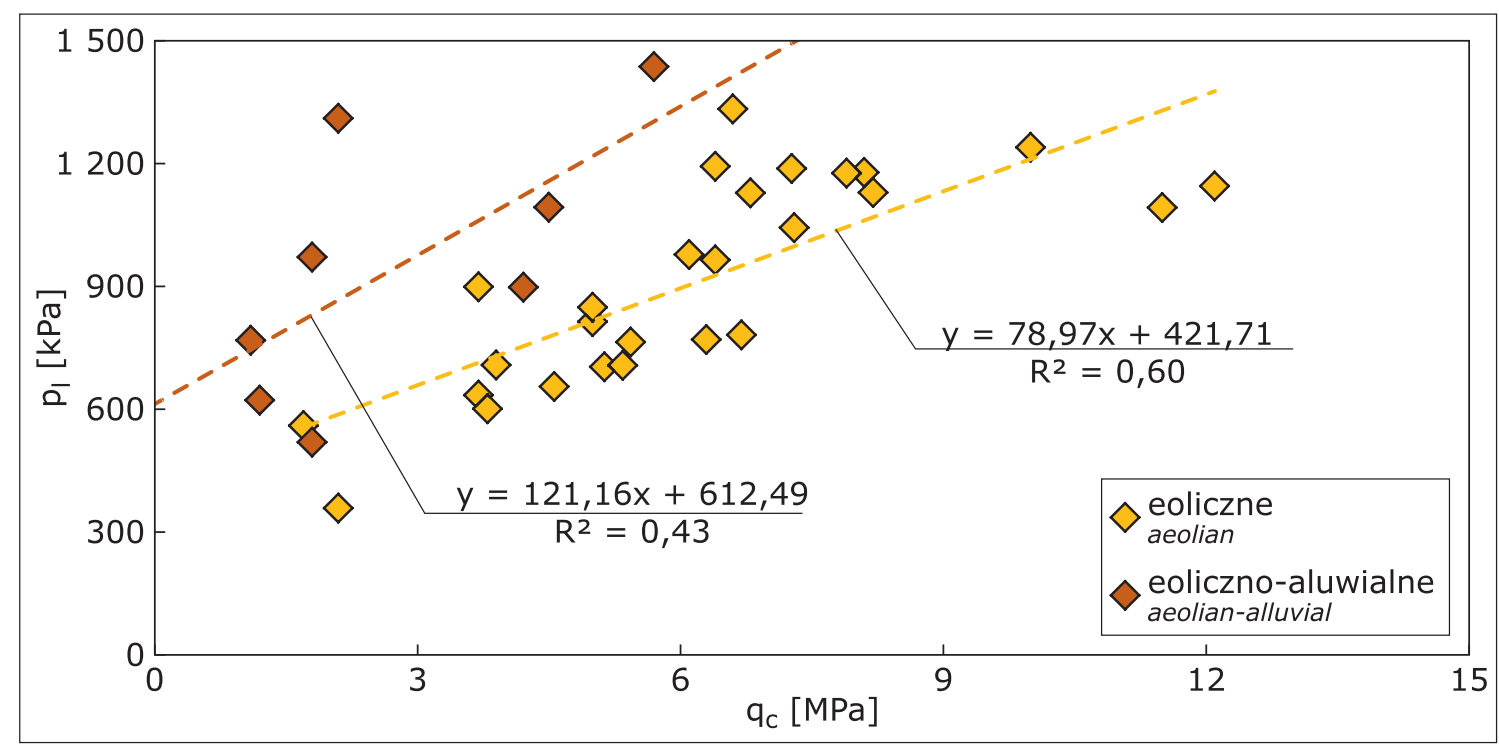

Ryc. 13. Zależność $q_{\mathrm{c}}-p_{1}$ dla lessów lubelskich

Fig. 13. The $q_{\mathrm{c}}-p_{1}$ relationship for the Lublin loess

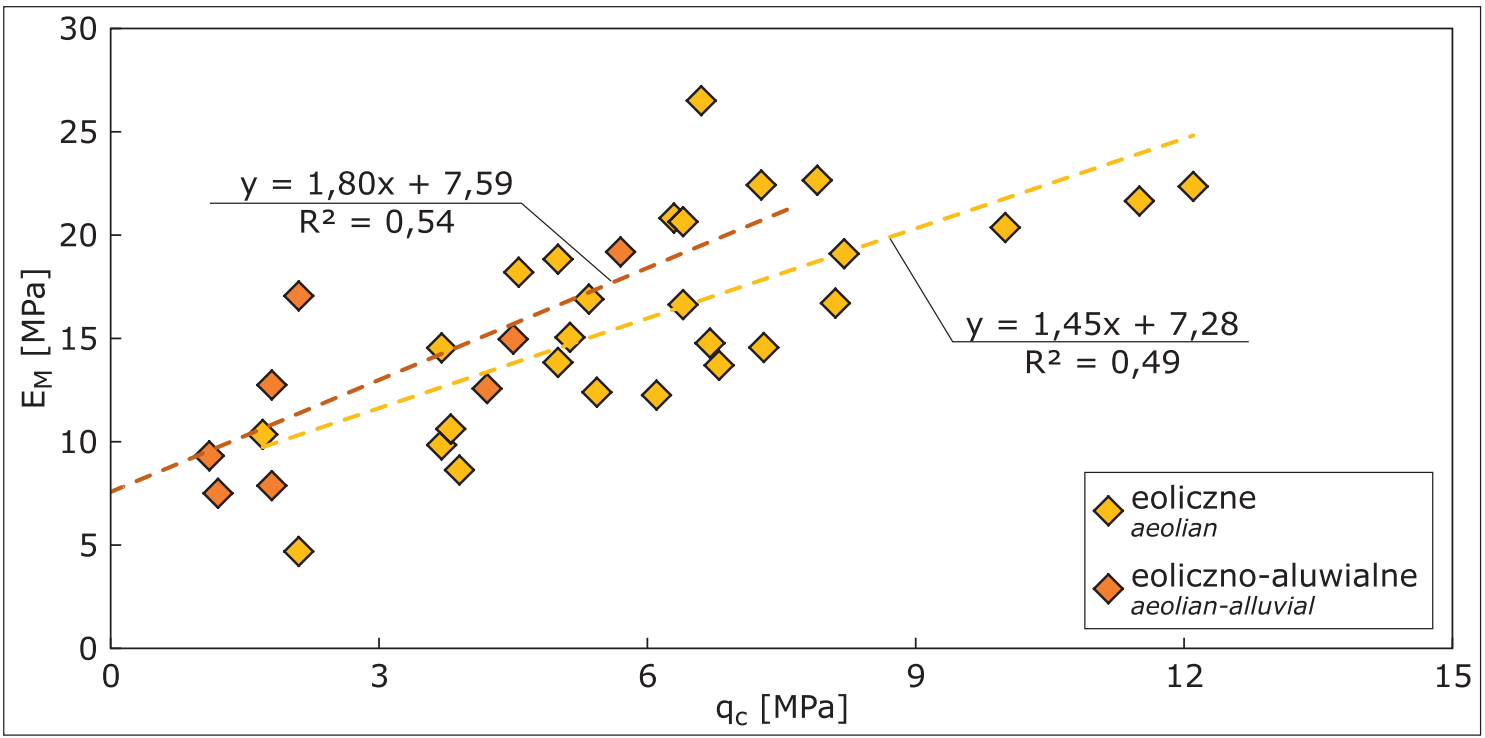

Ryc. 14. Zależność $q_{\mathrm{c}}-E_{\mathrm{M}}$ dla lessów lubelskich

Fig. 14. The $q_{\mathrm{c}}-E_{\mathrm{M}}$ relationship for the Lublin loess 
w praktyce w obrębie Lublina dotyczy jedynie niewielkiej jego części. Zgodnie z badaniami Borowczyka i Frankowskiego (1979) lessy zapadowe to te $\mathrm{z}$ facji eolicznej w stanie zwartym, których opory stożka $q_{\mathrm{c}}<3,0 \mathrm{MPa}$ lub spełniające kryterium wzoru [10]. Zwracają oni również uwagę, że zjawisko to występuje przede wszystkim w strefie przypowierzchniowej, co również potwierdzają obserwacje autora. Także wyniki badań presjometrycznych wskazują na niezapadowy charakter lessów. W świetle przedstawionych analiz jedynie 3,0 $\div 4,0 \%$ lessów w obrębie Lublina może być zapadowych i występują one zazwyczaj do głębokości ok. 3-4 m p.p.t.

Niewielki zakres lessów zapadowych nie obniża znaczenia testów in situ w tych gruntach. Wykresy $q_{\mathrm{c}}$ nie tylko pozwalają identyfikować strefy podatne na osiadanie zapadowe, ale przede wszystkim dają obraz sztywności gruntu. Jak można zauważyć rozrzut wartości $q_{\mathrm{c}}$ jest bardzo duży. Wykresy z sondowań CPT stanowią bardzo dobry podkład do opracowania prawidłowych modeli podłoża lessowego na cele projektowe, co nie jest możliwe na podstawie samych odwiertów. Dlatego rekomenduje się tę metodę jako wiodącą w badaniach na cele budowlane. Przykładowe, reprezentatywne przekroje geotechniczne lubelskiego podłoża lessowego przedstawiono na rycinach 15 i 16. Omówione analizy dotyczą lessów w rejonie Lublina, jednak wnioski można odnosić do lessów na całym Płaskowyżu Nałęczowskim.

\section{WNIOSKI}

Po analizie przedstawionych danych autorowi nasuwają się następujące wnioski:

1. Lessy lubelskie można podzielić na trzy główne grupy facjalne: eoliczne (lessy typowe), eoliczno-deluwialne oraz eoliczno-aluwialne. Lessy powstałe przy współdziałaniu innych procesów (np. koluwialnych, soliflukcyjnych, limnicznych), gdy stanowią niewielki odsetek, można zaliczać do głównych grup. Lokalnie, gdy te procesy wpływają wyraźnie na budowę podłoża, powinno się je wydzielać jako osobne grupy.

2. Najbardziej rozpowszechnione w Lublinie są lessy typowe, czyli pylaste facji eolicznej, która wg autora stanowi ok. $75-80 \%$ i ich parametry mają kluczowe znaczenie dla projektowych obiektów budowlanych. Pozostałe grupy facjalne to ok. $8-15 \%$ dla lessów eoliczno-deluwialnych oraz 8-10\% dla lessów eoliczno-aluwialnych.

3. Lessy zapadowe stanowią niewielki odsetek na terenie Lublina, wg autora jest to ok. 4-5\%. Ich obecność i zasięg można identyfikować terenowymi testami CPT lub PMT, a dokładną wartość wskaźnika osiadania zapadowego $i_{\text {mp }}$ należy wyznaczać w badaniach laboratoryjnych.

4. Lessy typowe są makroskopowo jednorodne, jednak ich zmienną sztywność odzwierciedlają testy wykonywane in situ. W lessach należy wydzielać warstwy geotechniczne opierając się głównie na testach in situ.

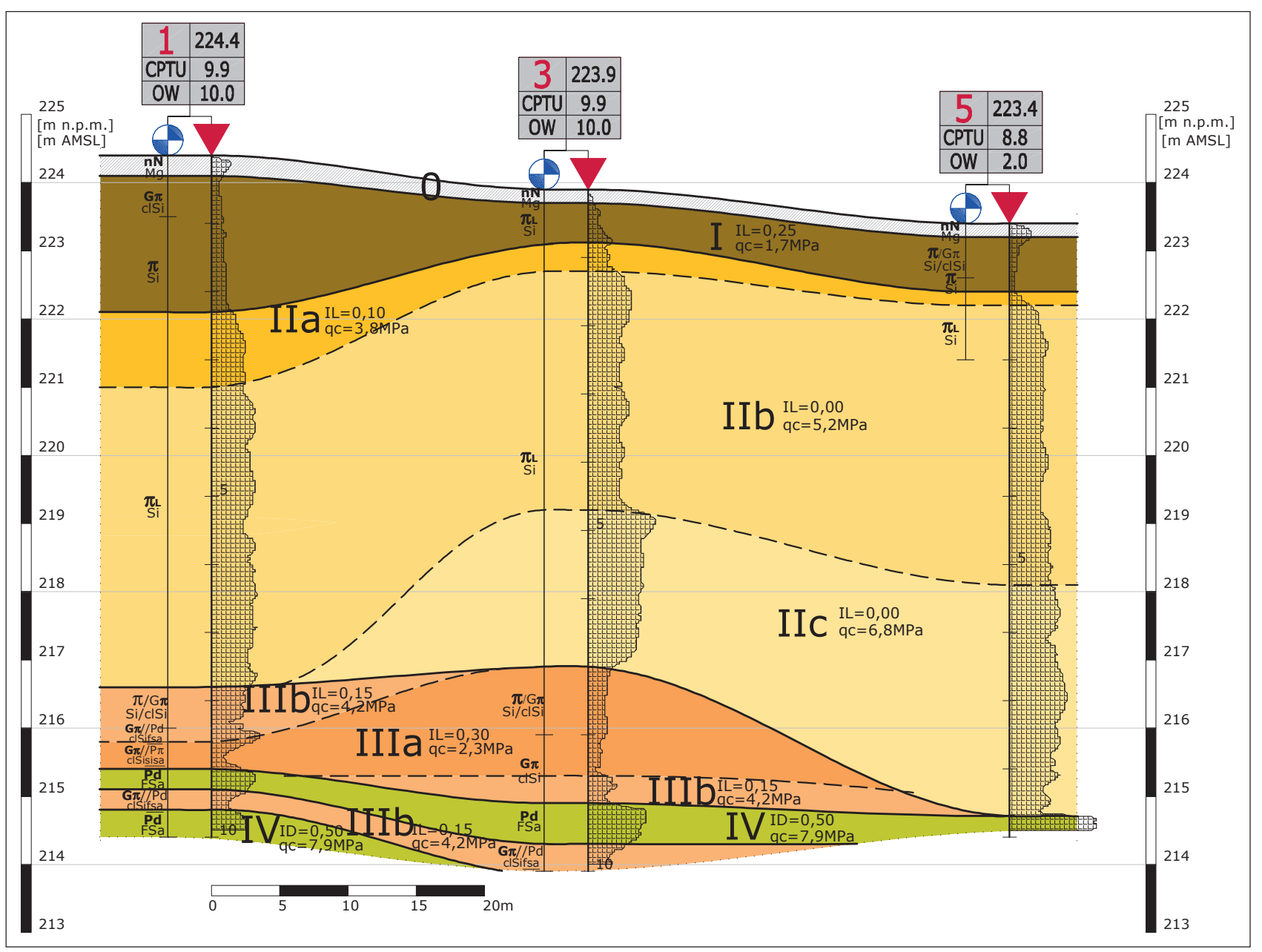

Ryc. 15. Przekrój geotechniczny podłoża lessowego w rejonie ul. Granatowej w Lublinie

Fig. 15. Geotechnical cross-section of the loess subsoil in the area of Granatowa street in Lublin 


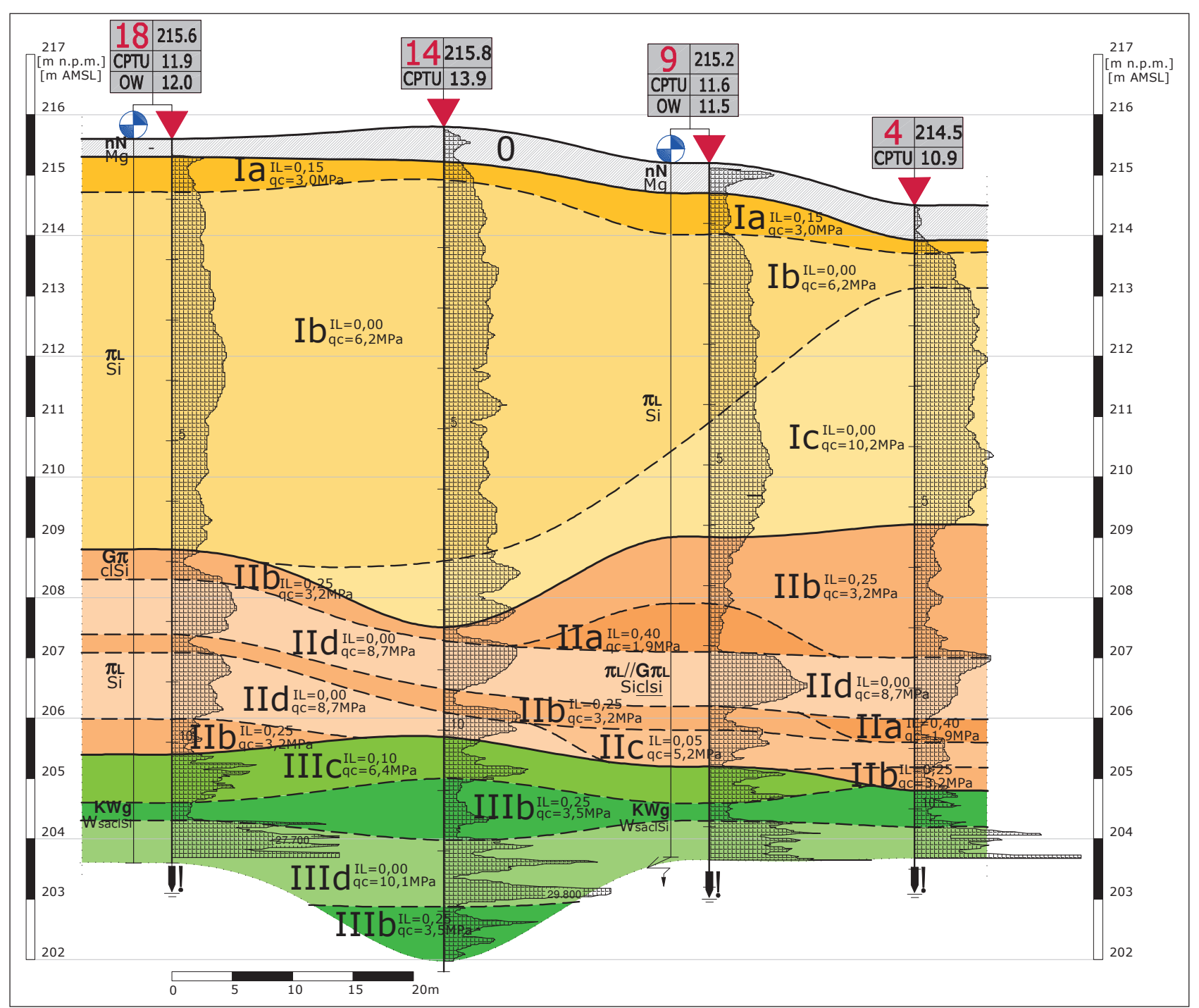

Ryc. 16. Przekrój geotechniczny podłoża lessowego w rejonie ul. Nałęczowskiej w Lublinie

Fig. 16. Geotechnical cross-section of the loess subsoil in the area of Nałęczowska street in Lublin

5. Podstawową metodą badawczą podłoża lessowego powinny być sondowania statyczne $\mathrm{CPT} / \mathrm{CPTU}$, natomiast najodpowiedniejszym parametrem wiodacym dla warstw geotechnicznych - wartość oporu stożka $q_{\mathrm{c}}$. Uszczegółowienie budowy oraz parametrów należy wykonywać testami DMT, SDMT oraz PMT, a także badaniami laboratoryjnymi, których niezbędny zakres można ustalać po opracowaniu modelu podłoża $\mathrm{z}$ wyników sondowań statycznych.

6. Przedstawione dane z sondowań statycznych CPT/ CPTU sa reprezentatywne dla Lublina. Dane z testów DMT/SDMT można uznać za reprezentatywne, jednak potrzeba więcej badań dla ich uszczegółowienia i rozdzielenia ze względu na facje. Dane z badań presjometrycznych należy traktować jako wstępne. Zauważalne są trendy, jednak dla wyprowadzenia wiarygodnych zależności potrzeba większego zbioru danych. Po wyprowadzeniu zależności $q_{\mathrm{c}}-p_{1}$ można będzie szacować nośność podłoża bezpośrednio z sondowań CPT.

Autor składa podziękowania Recenzentom za cenne uwagi i komentarze, które wpłynęły na końcową formę oraz wartość merytoryczną pracy. Serdeczne podziękowania kieruje również do Współpracowników z firmy GeoNep oraz Politechniki Lubelskiej za pomoc przy realizacji badań polowych i tworzeniu obszernej bazy danych lessów.

\section{LITERATURA}

AMOROSO S., MONACO P., MARCHETTI D. 2013 - Use of the Seismic Dilatometer (SDMT) to estimate in situ G- $\gamma$ decay curves in various soil types. Geotechnical and Geophysical Site Characterization 4 Proceedings of the 4th International Conference on Site Characterization 4, ISC-4. Taylor \& Francis Books Ltd: 489-497.

ATKINSON J., SALLFORS G. 1991 - Experimental determination of soil properties. Proc. 10th ECSMFE, vol. 3, Florence.

BOROWCZYK M., FRANKOWSKI Z. 1977 - Nowe kryterium oceny osiadania zapadowego lessów określone na podstawie badań presjometrycznych. Inżynieria i Budownictwo, 3: 91-92.

BOROWCZYK M., FRANKOWSKI Z. 1979 - Zmienność właściwości geotechnicznych lessów w świetle współczesnych metod badań. Kwart. Geol., 23 (2): 447-461.

CILOGLU F., CETIN K.O., EROL A.O. 2014 - CPT-based compressibility assessment of soils. International Symposium on Cone Penetration Testing: 629-636.

EL HOWAYEK A., HUANG P.-T., BISNETT R., SANTAGATA M. 2011 - Identification and behavior of collapsible soils. Purdue University. Joint Transportation Research Program.

FELLENIUS B.H., ESLAMI A. 2000 - Soil profile interpreted from CPTu data. "Year 2000 Geotechnics" Geotechnical Engineering Conference, Asian Institute of Technology, Bangkok, Thailand, November 2730, 2000.

FRANKOWSKI Z., PIETRZYKOWSKI P. 2017 - Charakterystyki odkształceniowe lessów południowo-wschodniej Polski. Prz. Geol., 65 (10): 832-839.

GODLEWSKI T. 2013 - Interpretacja badań polowych a Eurokod 7. Acta Scientiarum Polonorum. Architectura, 12 (3): 61-72. 
GODLEWSKI T. 2018 - Evaluation of stiffness degradation curves from in situ tests in various soil types. Archives of Civil Engineering, 64 (4): 285-307.

GODLEWSKI T., SZCZEPAŃSKI T. 2011 - Nieliniowa charakterystyka sztywności gruntu (G0) - metody oznaczania i przykłady zastosowań. Górnictwo i Geoinżynieria, 2: 243-250.

KULHAWY F.H., MAYNE P.H. 1990 - Manual on estimating soil properties for foundation design. Electric Power Research Institute, New York. LAL A. 2019 - Research of the collapsibility of the European loess - review. Budownictwo i Architektura, 18 (1): 5-10.

LUNNE T., ROBERTSON P.K., POWELL J. 1997 - Cone penetration testing in geotechnical practice. CRC Press.

LUNNE T., BERRE T., ANDERSEN K.H., STRANDVIK S., SJURSEN M. 2006 - Effects of sample disturbance and consolidation procedures on measured shear strength of softmarine Norwegian clays. Can. Geotech. J., 43: 726-750.

LUO H., WU F., CHANG J., XU J. 2018 - Microstructural constraints on geotechnical properties of Malan Loess: A case study from Zhaojiaan landslide in Shaanxi province, China. Engineering Geology, 236, October 2016: 60-69.

MALINOWSKI J. 1971 - Badania geologiczno-inżynierskie lessów. Wyd. Geol., Warszawa.

MARCHETTI S. 1980 - In situ tests by flat dilatometer. Journal of the Geotechnical Engeenering Division, 105 (III): 299-321.

MARCHETTI S. 2015 - Some 2015 Updates to the TC16 DMT Report 2001. The 3rd International Conference on the Flat Dilatometer: 43-65.

MARCHETTI, S., CRAPPS D.K. 1981 - Flat Dilatometer Manual. Internal Report of G.P.E. Inc.

MARCHETTI S., MONACO P., TOTANI G., MARCHETTI D. 2008 In Situ Tests by Seismic Dilatometer (SDMT). Proceedings From Research to Practice in Geot. Engng., 180: 292-311.

MARUSZCZAK H. 2000 - Definicja i klasyfikacja lessów oraz utworów lessopodobnych. Przegląd Geol., 48 (7): 580-586.

MAYNE P.W. 2016 - Evaluating effective stress parameters and undrained shear strengths of soft-firm clays from CPTu and DMT. Proceedings of the 5th International Conference on Geotechnical and Geophysical Site Characterisation, ISC 2016, 1(July 2016): 19-39.

MAYNE P.W. 2020 - Use of in-situ geotechnical tests for foundation systems. Proceedings of the Széchy Károly Emlékkonferencia, (September): $12-73$.

MAYNE P.W. 2001 - Stress-strain-strength-flow parameters from enhanced in situ tests. International conference on in situ measurement of soil properties case histories.

MILLER H., DJERBIB Y., JEFFERSON I., SMALLEY I. 2000 - Collapse behaviour of loess soils. ISRM International Symposium. Melbourne: International Society for Rock Mechanics and Rock Engineering. MŁYNAREK Z., TSCHUSCHKE W., WIERZBICKI J. 1997 - Klasyfikacja gruntów podłoża budowlanego metodą statycznego sondowania. Materiały 11 Krajowej Konferencji Mechaniki Gruntów i Fundamentowania, tom 2. Politechnika Gdańska, Gdańsk: 119-126.

MŁYNAREK Z., WIERZBICKI J., MAŃKA M. 2015a - Geotechnical parameters of loess soils from CPTU and SDMT. [W:] Marchetti S., Monaco P. , Viana da Fonseca A. (red.), International Conference on the Flat Dilatometer DMT'15 Rzym: 481-489.

MŁYNAREK Z., WIERZBICKI J., MAŃKA M. 2015b - Moduły ściśliwości i ścinania lessów z badań CPTU i SDMT. Inżynieria Morska i Geotechnika, 36 (3): 193-199.
MONACO P., AMOROSO S., MARCHETTI S., MARCHETTI D., TOTANI G., COLA S., SIMONINI P. 2014 - Overconsolidation and stiffness of venice lagoon sands and silts from SDMT and CPTU. Journal of Geotechnical and Geoenvironmental Engineering, 140 (1): 215-227.

NEPELSKI K. 2020 - Numeryczne modelowanie pracy konstrukcji posadowionej na lessowym podłożu gruntowym. Politechnika Lubelska, Lublin.

NEPELSKI K. 2021 - Parametry odkształceniowe lessów lubelskich wyznaczone z badań CPTU, SDMT oraz Presjometrem Menarda. Przyrodnicze i Geotechniczne Aspekty Budownictwa, Poznań: 47-56.

NEPELSKI K., LAL. A. 2021 - CPT Parameters of Loess Subsoil in Lublin Area. Applied Science, 11 (13): 6020.

NEPELSKI K., RUDKO M. 2018 - Identyfikacja parametrów geotechnicznych lessów lubelskich na podstawie sondowań statycznych CPT. Przegląd Naukowy Inżynieria i Kształtowanie Środowiska, 27 (2): 186-198.

NEPELSKI K., LAL A., FRANUS M. 2016 - Analiza wyznaczania konsystencji lessów lubelskich na podstawie wyników sondowań statycznych CPT. Budownictwo i Architektura, 15 (4): 183-194.

NEPELSKI K., LAL A., GRZEGORCZYK M. 2019 - Comparative analysis of the CPT results obtained with the use of electric and mechanical penetrometer cone. Proceedings of the XVII ECSMGE-2019: 1-7.

NORMA PN-EN ISO 14688-1:2006 - Badania geotechniczne. Oznaczanie i klasyfikowanie gruntów. Część 1: Oznaczanie i opis.

PAJ A. 2007 - Osiadanie zapadowe lessów Wzgórz Trzebnickich i Płaskowyżu Głubczyckiego. Geologos, 11: 375-382.

POWELL J.J.M., LUNNE T. 2005 - Use of CPTU data in clays/fine grained soils. Studia Geotechnica et Mechanica, 27 (3/4): 29-66.

RABARIJOELY S. 2019 - Evaluation of correlation between parameters from CPTU and DMT tests and soil type behavior chart. Annals of Warsaw University of Life Sciences - SGGW. Land Reclamation, 50 (4): 313-326. RADASZEWSKI R., STEFANIAK K. 2017 - Problem wyznaczania wytrzymałości na ścinanie gruntów przejściowych. Prz. Geol., 65 (10): 864-872. ROBERTSON P. K. 2009a - CPT-DMT Correlations. Journal of Geotechnical and Geoenvironmental Engineering, 135 (11): 1762-1771.

ROBERTSON P.K. 2009b - Interpretation of cone penetration tests a unified approach. Can. Geotech. J., 46 (11): 1337-1355.

ROBERTSON P.K., CAMPANELLA R.G., GILLESPIE D., GREIG J 1986 - Use of Piezometer Cone Data., June 1986: 1263-1280.

SANGLERAT G. 1972 - The penetrometer and soil exploration. Amsterdam: Elsevier.

SENNESET K., JANBU N., SVANO G. 1982 - Strength and deformation parameters from cone penetration tests. Proceedings of the 2nd European Symposium on Penetration Testing. Amsterdam: 863-870.

SIMONINI P., RICCERI G., COLA S. 2007 - Geotechnical characterization and properties of Venice lagoon heterogeneous silts. Characterisation and Engineering Properties of Natural Soils, 4: 2289-2327.

SZULBORSKI K., WYSOKIŃSKI L. 2004 - Ocena współpracy konstrukcji z podłożem w diagnozowaniu uszkodzeń budowli. [W:] Mat. VIII Konf. „Problemy rzeczoznawstwa budowlanego”. Cedzyna.

TARNAWSKI M. 2007 - Zastosowanie presjometru w badaniach gruntu. Warszawa, Wyd. Nauk. PWN.

TRUTY A. 2008 - Sztywność gruntów w zakresie małych odkształceń Aspekty modelowania numerycznego. Czasopismo Techniczne, 3: 107126.

WIŁUN Z. 2013 - Zarys geotechniki. Wyd. Komunikacji i Łączności.

Praca wpłynęła do redakcji $16.06 .2021 \mathrm{r}$

Akceptowano do druku 3.11.2021 r. 